\title{
She Enjoys Idioms and Fables
}

\author{
Yunxiang Zhang
}

\section{Interview with Miss Li Lin's Mother and Li Lin}

Li Lin, female, born in 1976. Only child. Grade III intellectual disability. No schooling. Joined a subdistrict Sunshine Home ${ }^{1}$ in 2005.

Interviewees: Chengzhi Wang (Li Lin's mother) and Li Lin

Interviewer and writer: Yunxiang Zhang

Interview date: October 27, 2016 and December 14, 2016

Interview place: A McDonald's restaurant in Xuhui District, Shanghai

\section{An Educated Youth Who Returned to Shanghai and Married Late}

Q: How did you get to know your husband?

Lin's mother: It was a marriage arranged by our parents.

Q: Did your parents arrange your first dates?

Lin's mother: No, they didn't, I got to know him through one of my colleagues, but I didn't like him at first. Why did I still marry him? Because I was pushed by my family and other people around me. I wasn't young when I returned from the

\footnotetext{
${ }^{1}$ The Sunshine Home's proper name is the Sunshine Disabled Home, a government-run non-profit institution that serves disabled adults throughout Shanghai. It was set up by the Shanghai government as part of 'the Sunshine Movement for People with Intellectual Disabilities' in 2005. The main aims of the institutes are improving the independence, social skills, and working capabilities of 16- to 35 -year-old disabled people in the community by encouraging them to become more involved in community life.
}

\section{Y. Zhang $(\bowtie)$}

East China Normal University, 3663 Zhongshan Bei Road, Shanghai 200062, China 
countryside, I'd been there for several years after graduating from high school in 1968. The truth was, I didn't go to school until I was 10 because I had a birth defect and was a slow developer.

When I came back Shanghai at the age of 28, straight away, I was getting the same questions from everybody: "Do you have a boyfriend? Are you married? You're not young anymore, you should get married soon." At the same time, my mother-she used to be a teacher-developed a mental illness during the Cultural Revolution that developed into dementia. I married my husband even with all these social and family pressures.

Q: When did you get married?

Lin's mother: When I was 30, in March 1976.

Q: What kind of work did you do during that period?

Lin's mother: Li Lin's dad worked with technology. When I came back to Shanghai, I was in a bad state which affected my health, so I looked for an easier job, working in the canteen of a dye factory.

Q: Did you both work at the same place?

Lin's mother: No, we didn't, my husband worked at the Shanghai Color Printing Factory, I worked at the Second Printing and Dyeing Mill. It was a marriage arranged by our parents and we only had one child.

\section{An Infant Born with a Vacuum Delivery}

Lin's mother: I was pregnant soon after we got married and I had the baby in December.

Q: The child was born in December?

Lin's mother: That's right. After a ten-month pregnancy, I gave birth on 17 December. I took her to a children's hospital when she was 18 months old and was told she had some kind of a brain problem. Until that time, we hadn't realized she was... People used to call this kind of child an "idiot"; there wasn't a name like intellectually disabled at that time.

Q: Were you told what had caused her problem?

Lin's mother: It all came down to me and my health problems. When I was working on the farm as an educated urban youth, one night I hurt myself badly in a fall.

Do you know about the Cultural Revolution? Have you seen any TV programs about that period? At that time, we had to follow "the early request and late report" rule, and we had meetings every evening. That place only had rough concrete roads; that was the cause of my fall and my tailbone was broken. However, we didn't have a medical service and nobody treated this problem seriously, even me. It healed by itself and my tailbone has been bent ever since then.

This problem affected the delivery. A normal birth usually takes around $10 \mathrm{~h}$, but after my waters had broken my child didn't come out for over $54 \mathrm{~h}$. It was almost dry by that time and the infant got cerebral hypoxia. The doctor used oxytocin, but it didn't work, and finally the doctor found out that my tailbone was bent and 
that was causing the problem. The doctors ran out choices and they had to do a vacuum delivery. So my daughter had cerebral hypoxia at first and was injured by the vacuum process; these two things damaged her brain. The vacuum delivery left a big soft swelling on my daughter's head. Anyway, my child had an intellectual disability after this.

Q: How did you feel?

Lin's mother: My heart was broken. I cried every day until my daughter was in her late teens. As you can imagine, people spoke ill of me behind my back and said I was having an unhappy family life and I'd got a disabled child. I was trapped at home and outside. I pulled through this difficult situation. Now people call me the "iron woman", but they don't know the reason or why.

People gave me a lot of advice, for example one colleague who I called auntie used to encourage me: "Xiao Wang, you must be brave and strong in this situation. You should learn something from Ah Q, the character in the Xun Lu novel, ${ }^{2}$ you have to know when to stop thinking if you can't figure out a solution to the problem. It's best to live like Ah Q, a bit crazy but strong; you have to smile all the time, let it be and take it easy."

I was really inspired by her words; if I hadn't listened to her, I probably wouldn't have a family today. In my family, my mother was ill, I didn't get on with my husband, I totally lost hope and cried every day. When my daughter was little, my face was always covered in tears. I used to cry and get upset after I hit my daughter when she had done something wrong.

When she was little, it was difficult to send her to the babysitter's place. There was a direct bus from my work, but I had to go in a different direction to go to the babysitter's home, then take a bus from her place, it was a much longer journey. How hard that journey was. As a small person, for me the worse part of the bus journey was getting my daughter on and off the bus, she didn't have much control over her body. I remember, once, we fell down together, I injured my leg and my daughter cracked her head. Both of us were crying, but I was unable to pick her up at that moment, especially with an injured leg. Who would pity you? Nobody.

I worked at the logistics department at first, but my boss moved me from the office job to a much worse job-a staff canteen cleaner-cleaning and washing vegetables: I didn't even belong to the canteen department. My story was just like Xiaoping Deng's, who dropped down and was then promoted afterwards, several times. Finally, I got promoted too.

Q: Couldn't you tell she had a problem when she was an infant?

Lin's mother: When she was a baby, she just made some noises from time to time; when she was happy, she would jump or kick her legs, but I didn't think that was a problem, because I had been a slow developer too. I was only able to walk when I was seven, so I thought my daughter was probably just like me, a late developer in

\footnotetext{
${ }^{2} \mathrm{Ah} \mathrm{Q}$ is a famous character in modern Chinese literature who came from one of Xun Lu's masterpieces The True Story of $A h Q$ in 1922. As a poor peasant with little education, Ah Q had a difficult life and he had to use his well-known 'spiritual victories' - a kind of mad trick-to lift his self-esteem to an acceptable spiritual 'superior' level from the sufferings and the bullies he encountered.
} 
speaking and walking, more than ordinary children. I never thought she had a mental problem.

Q: When did she start speaking and walking?

Lin's mother: When she was four. She spoke well but with broken up sentences and a small vocabulary. If you blamed her for something she'd done, she couldn't explain herself. Not like today, if something happens to her, she can reason with you and talks all the time. Nowadays, you have to be careful when you judge her.

Q: Did you have any other problems other than learning to walk late?

Lin's mother: No, I was fine. I could walk at seven, but I couldn't go to school the following year, because I hadn't grown up enough. For the same reason, the school registrar rejected me three times until I was ten; my mom was so worried and she said to the teacher: "Please ask her some questions, my daughter knows everything!" When I finally started school, I became known as a good student straight away, because my body was small but my mental age was equal to a fourth year student; so the first 2 years of study was very easy for me. According to superstition, if a man is too clever, it might prove to be a negative for his children's luck and intelligence; a saying that works for me at least: I'm a really competitive person but my daughter is weak.

Q: Did you find out about your daughter's condition from the doctor when she was 18 months old?

Lin's mother: Yes, we found out she had a mental problem, but before then, when she was 10 months old, she started shivering and was kept in the ward for several days. Nobody could say what the problem was, but she was just sweating heavily, her forehead was sweaty, but her chin was cold and she was covered with a cold sweat. I mopped her face with a handkerchief, but it was soaking wet within half an hour. She was sweating all the time, she couldn't say anything of course, but she shivered with cold.

After four days of tests and exams the doctors still couldn't diagnose her problem, but I overheard some of their conversations and they thought my daughter might have a brain disease.

Q: Did she get sick before that?

Lin's mother: No, she was quite healthy before.

Q: Did she have a cold or something like that before?

Lin's mother: Well, she didn't have any sickness when she was very little, but she started getting viruses from time to time when she had grown up a bit.

Bringing her up to what she is now was the best thing I could do for her. When she was born, she was cross-eyed and you could hardly see her pupils, they were tiny; her head was crooked, leaning to one side, and she walked in a very awkward way.

Anyway, when she was born like this and lots of people said to me this girl isn't worth raising any more, but she was my daughter and I couldn't give her up, no way. 


\section{Ten Years' Looking for Medicine}

Lin's mother: Since I knew she had a brain disease, I started to look for specialists in hospitals through my contacts. There was a relative of a classmate who worked at a hospital of traditional Chinese medicine at the crossroads of Shimen Second Road and Nanjing Road. He helped me find some of the latest medicine for the infant's problem; he used his contacts to help me until he moved to Hong Kong. I tried all kinds of new medicine, whatever I could get for my daughter. My salary wasn't much, but I saved every penny that I could to buy these pills.

Q: How old was your daughter at that time?

Lin's mother: I stopped looking for treatment and medicine when she turned ten.

Q: Do you mean from the time that you first noticed her problem until she was ten?

Lin's mother: Yes, that's right, I never stopped trying new medicine for her during that time. Once we tried acupuncture, during the treatment the doctor put more than 20 gold needles in her head. I only stopped looking for treatment when she was ten.

At that time, through one of my contacts, I saw a very good pediatrician in the Children's Hospital. The doctor told me: "You shouldn't give your daughter any more new pills, there isn't anything that can cure her problem. All of those so-called new drugs on the market can't sort out her problem. The promotional statements on these drugs is just there for the patient's parents, there's no proof that it works. Don't be fooled and waste any more money." It's why I stopped trying new drugs.

Q: Did those drugs do anything good for your daughter?

Lin's mother: Not really. The problem with her eyes was sorted out by surgery when she was six. I wasn't sure if it would work; I thought I was just fighting a losing battle.

Q: An operation?

Lin's mother: Yes, an eye operation for her crossed-eye. Before the operation, many people told me that my daughter didn't need surgery, a pair of special glasses would do the job.

Later, I took her to the hospital at the crossroads of Huaihai Road and Fenyang Road and I happened by chance to meet the Dean that time. He said to me: "Glasses won't be able to cure your daughter's eyesight, she needs an operation." He also explained the condition to me: "Her optic nerves are paralyzed and aren't flexible anymore, only an operation will be able to sort out this problem, not a pair of glasses." So my daughter had eye surgery and after that, I started focusing on her crooked head by telling her off to stop her.

Q: When did she stop tilting her head to one side?

Lin's mother: She was cured after an operation when she was six.

Q: Well, I guess you spent quite a lot of money on her.

Lin's mother: Oh, I wouldn't say that. 


\section{A Mother Eager to Do Everything Well}

Lin's mother: I spent all my days in tears after my daughter was born and I was always thinking about how I could have a baby like this; how could a strong person like me have a disabled baby?! (A forced smile) I couldn't work it out and I really struggled with the problem.

I couldn't be at ease when I thought about what would happen to my daughter after I died-who would look after her? I heard so many miserable stories about children like her, I couldn't trust anybody. Finally, there was only one thought leftI'll strangle her before I die-we have to live and die together. I couldn't give her to anybody else. This idea came to mind all the time.

Sometimes, I got angry with my daughter when I felt very bad, I even hit her. I used to cry for a long time after I hit her, because I really pitied her. I can't think about how difficult my life had been bringing up my daughter in this situation-a mother who had dementia and a bad relationship with my husband-I can't stop crying when I think back about that time.

All my colleagues looked down on me after I gave birth to this poor child. I was so keen to do everything the best I could but even this didn't help me win respect. Those older female colleagues-we used to call them aunties- they had little or no education and were quite nasty. The truth of the world is that people envy a man when he's wealthier than them and despise him when he has a worse life. Oh, there was an auntie, she liked to talk about other people behind their back so much, and she liked saying bad things about me. I was a fast worker and used to finish my whole day's duty within $2 \mathrm{~h}$. After that, I liked to help one of my colleagues, she was my boss as well. After a while, she was promoted and I got her position.

At the same time, I was doing an adult education degree, because I had only finished my high school study when I left Shanghai and went to the countryside farm during the Cultural Revolution.

I'm a very proud person, some of my colleagues liked to do outside work during their working time, but I wouldn't have been able to pay the price and lose face if I'd been caught doing this, so I told myself I mustn't do this. After I finished my own work, I would either cover for a colleague, who I just mentioned, or read. I was the kind of person who wanted to do better than everybody else.

Q: Did you find a place to study by yourself?

Lin's mother: Yes, I took up a place in the Arts in a high school after I passed the entrance test; I had graduated from a high school before that, but never received a certificate because the Cultural Revolution interrupted everything.

Actually, since I was young, I was good at science subjects but not arts subjects. When I was a high school student, Chinese exams were my weakness. I wasn't good at practical writing or rhetorical writing, so my Chinese score was just above $50 \%$ and not enough to pass the exam. Then there was PE; that was difficult. Except for these two modules, I used to get $95 \%$ in all my other exams. After Ire-sat this level, I did a technical secondary school level accounting degree.

$\mathrm{Q}$ (smiles): Well, you did quite a lot of exams! 
Lin's mother(laughs): You're right, I have a lot of report cards and I still keep them, a big pile of them.

Q: You're brilliant.

Lin's mother: But I wasn't able to do anything about my daughter. There is an old saying, "don't lose on the starting line", but I lost all my credits when my daughter was born (laughing).

\section{She Left the Nursery and Primary School}

Lin's mother: I'm a very proud person, but I got stuck in a rut after I had my daughter. I had problems with both family and at work. Nobody could look after my daughter while I was at work, my mother couldn't look after a child, and my mother-in-law was a tiny person and she couldn't do it either.

Q: Nobody helped you with babysitting?

Lin's mother: The only choice I had was to put her in the factory's nursery. There was a teacher who treated my daughter quite badly. She was a college graduate and could inject drugs, so I gave my daughter's injections to her-they had to be kept in the fridge until used-and I asked her to inject my daughter when required. While I was there, she put the drugs in cold water and promised me that she'd inject my daughter soon. So I left and didn't insist that she did this immediately because I thought it wouldn't do any harm if the injection was delayed for a short while.

During that period, I was in charge of the food coupons and my office was just next to the nursery.

Q: The two places were very close?

Lin's mother: Yes, both of us worked in the logistics department.

Later that day, I saw an injection bottle in the public bathroom and realized that it was my daughter's drugs. It made me angry. I went back to the nursery and asked the teacher if she had injected my daughter. That teacher said: "Of course I did, you can ask around if you don't trust me." She looked very confident. But I couldn't check further with the witnesses she mentioned, because at that time I was being bullied by my boss; everybody discriminated against me, nobody trusted me.

One temporary worker told me: "Auntie Wang, please don't say anything else, because you can't win this battle with them." He also said he knew I told the truth, but in his situation, he couldn't support me. He also suggested that I should take my daughter to the affiliated hospital for her injections. After that, I stopped sending my daughter to the nursery but took her to work with me.

Sometimes, the gate guards would stop my daughter going into the factory, so I had to leave her at the guardhouse. I didn't care about saving face anymore. After I found out about my daughter's condition, I stopped worrying about any public reputation and stopped all of my other family duties to look after her. That day, I let the guards choose, if they didn't let her inside with me, the only thing I would be able to do is leave her with them. If she came into the office with me, she had to sit 
on a stool that looked like a toilet seat, which had a hole in the middle, for $8 \mathrm{~h}$ until I finished work.

Q: Did she do anything else?

Lin's mother: No, she would just sit there.

Q: Was she well behaved and sat there for the whole day?

Lin's mother: She was a silly child, there wasn't anything else she could do.

Q: How old was she when she started going to the office with you?

Lin's mother: She went to the nursery until she was 20 months old, later she was looked after by her first nanny, a nursery teacher's mom who retired from work with a large number of workers of her age in 1979. She told me: "Xiao Wang, don't cry anymore, I'm retired now and I can care for your daughter."

Q: When your daughter was over 20 months old?

Lin's mother: Yes, my daughter stayed with her for around 3 years. This auntie had a very introverted son, kind of autistic, perhaps. With the experience of looking after her own son, she said: "I don't think she'll be like this forever, let me try to bring her up in my way."

I told her that my daughter wasn't a clever person, but she was very patient with her. The surprising thing was she taught my daughter to play with building blocks, she could even build some complex buildings. My daughter proved that she was a child worth teaching, right? She certainly did that.

Q: How did you feel when you saw her block buildings?

Lin's mother: I was pleased that she could do such a thing. People called her an idiot, meaning she was totally useless, but this achievement certainly proved that she was better than everybody had thought. Since then, I started to buy her only educational toys that were good for developing her intelligence.

She was a slow learner and couldn't keep still for long. No school wanted her. In those days around the end of the 1970s to the early 1980s, there were no special schools. Even if there had been such a school, I wouldn't have believed it could treat the children well enough. I was worried that it wouldn't do anything for her intellectual development if I sent her to a charity place, especially when she was just starting to develop her intelligence. It was better to let her stay in society.

Q: What do you mean by letting her stay in society?

Lin's mother: Keeping her at home, a place outside school.

Q: Did she go to a primary school?

Lin's mother: She only attended a regular primary school for a month. During that month, her teacher came to me and complained about her behavior all the time. I tried very hard to avoid being confronted by the teacher until I had no choice. Finally, the school forced me to take her out.

Q: What was her school performance like?

Lin's mother: She couldn't sit still in the classroom and she distracted the other students quite often. On the day I enrolled her at the primary school, she was sick and I carried her in my arms, so the teachers of the Baoding Road Primary School didn't see her problem. But in the classroom, when the teacher asked the students to take out their books and pencil boxes, my daughter, after she had taken her things out, would run up to the other students and started shouting: "Take out, take out, take 
out your stuff..." Her behavior disturbed the class. She kept doing this kind of thing in that one month at school and I had to hide from her teacher and his complaints. Can you imagine what I felt like at that time? It was a very difficult period for me, and I couldn't stop myself thinking about what would happen to her when I died.

Q: So after that you had to keep her at home and look after her yourself?

Lin's mother: Yes, I've kept her at home since then.

\section{A Girl Enjoyed Care of Many Families}

Q: Who took care of the child when you were at work?

Lin's mother: When my daughter was about 7 or 8 years old, there wasn't a single person to look after her, so I had to leave her with my mother. But because of my mother's health condition-she was suffering from dementia-she couldn't look after my daughter properly and even had a damaging effect on the girl. This experience made my daughter even worse. My mother was paranoid and was always thinking that somebody was trying to hurt her, like her food would be poisoned and she had to eat in a locked cupboard with all of the cracks sealed. After that, she had to wear a mask all the time. People kept telling me that I mustn't leave the child with her, but I didn't have a choice.

My mother passed away when my daughter was ten and I had to leave her with my mother-in-law, even though her condition didn't really allow her to take this kind of responsibility. Fortunately, by then, Li Lin was a little older and easier to look after. But my daughter kept making all kinds of trouble when they were together, I couldn't relax while I was at work, I worried about them all the time, thinking she might throw the washing-up bowl on her grandma's head or set fire to the home.

Our old home on Haining Road was a wooden ranch-style building built by the Japanese; a fire was the last thing you wanted-it might burn down the whole area. Once I caught my daughter playing with fire at home, but we were lucky our downstairs neighbors saw her and put out the flames. They were shopkeepers and his family lived on the ground floor. They had come up to use our gas stove. That day, they found a fire when they came up to cook their dinner. The two families were quite close and I used to share some nice dishes with them. As a return favor, they kept an eye on my family for me when I wasn't there.

Anyway, that was how my daughter grew up, she was raised by many different families. After my mother died, one of her neighbors looked after the girl for several months and after that, she stayed with my mother-in-law's neighbor for a while. Actually, my daughter was raised by too many people, I can't even remember how many.

Even though I never felt at ease while I was at the office, especially when she stayed with my mother-in-law, any phone call from the family would drive me mad, and in addition to my daughter, I was also worried about her paternal grandma. If anything bad happened to her, my four sisters-in-law would definitely give me a hard time. 
Q: Do you mean your husband's family?

Lin's mother: Yes. During that period, we lived with my mother-in-law, but we had to looker after more people than that. One of my sisters-in-law came often with her husband and their two children and somehow, in addition to looking after my mother-in-law, we had to look after the extended family.

Q: Did this paternal auntie and her family live with you?

Lin's mother: No, they didn't, but they came for meals and stayed for a long time quiet often. At the same time, they looked down on us. My daughter used to complain about her auntie and her family, they would share some special food without her or only gave her a tiny piece.

Q: She could understand this idea of "how much"?

Lin's mother: Of course. I said to her: "Mom earns a salary and we aren't short of money; don't complain to anybody else except me if you think you've been treated unfairly by somebody, I'll buy you what you want." At the same time, my husband wanted me to be in charge of all the family finances, and I refused, how I could take care of so many people? I didn't want to argue with anybody about family issues, especially when I knew my husband's and my salary wouldn't be enough to feed this big family. I played ignorant and let my husband be the boss of the family while I just cared about the money in my own pocket. I insisted on one thing from my husband, he could spend his last penny on his family if he wanted to, but when the money ran out, he'd have to ask his family for help, not me. If they refused to pay anything for their daily expenses, that would be the end of their relationship.

Fortunately, my niece and nephew, his sister-in-law's children, were sophisticated people. They used to give my husband money without my knowledge from time to time. My mother-in-law wasn't an educated person, but she knew these family rules well enough and she used to give money to my husband secretly. In this situation, I just pretended I didn't know anything.

After Li Lin complained to me about being treated unfairly by these relatives, I started taking her out after work if they were there. At that time, I worked in the logistics office and was in charge of the canteen, our working time was from 6 a.m. to 2 p.m. I used to take my daughter out when I got home from work. Our home was on the Haining Road and Sichuang Road-a busy and bustling area-I used to buy her snacks and teach her something while we strolled around the streets.

Q: It was just the two of you who went out together, when the auntie and her family were at home?

Lin's mother: Yes, they weren't my responsibility. I bought my daughter whatever she wanted and taught her as much as I could. I never criticized her at home when she did something wrong, but I'd discussed her problems with her when we were out, I used to say to her: "Today, you were wrong when you talked to your dad in that way, you weren't very nice to him."

Q: Do you mean that you didn't criticize Li Lin in front of your husband?

Lin's mother: No, I didn't. I usually talked about her problems while we walked around the city. The first time, I just pointed the problem in a nice way, but if she made the same mistake again I'd criticize her and question her: "Why did you do that again?" If the same thing happened a third time, I might scold her. I was strict 
with her and I would set down the rules for her all the time, criticizing and scolding her quite often when she was young.

Q: Did it work?

Lin's mother: Not really, she was too naughty to keep in line.

Q: What about her father? Did he take care of her?

Lin's mother: Yes, but there wasn't very much he could do except criticize her. He didn't spend very much time with her, because he was busy with his work. He wasn't a patient person with the child. These days, Li Lin is great with housework, but she's still criticized by her dad.

Q: Has he changed his attitude?

Lin's mother: He isn't satisfied with her improvement and he still thinks she isn't smart enough.

Q: Is there a kind of bias in him?

Lin's mother: Well, I stopped worrying about how I look in other people's eyes, or thinking about losing face in public, but her dad has the opposite attitude. Not one of his bosses and colleagues knew anything about our daughter until he retired. He used to give ambiguous answers when his colleagues asked about his child's education or marriage prospects. Some of his colleagues only found out the truth when they got in touch with him after he'd left his job. Very few people in his workplace knew about our daughter.

Q: Was he really afraid of losing face?

Lin's mother: Yes, he's that kind of person. In accordance with the worker's welfare policy, all workers should receive some subsidy and temporary finical support for a disabled child, but my husband was too proud, he cared about his face, not the subsidies.

Q: What about your colleagues?

Lin's mother: Of course, they were biased against my daughter as well. I was a pretty capable employee and I received an important position from the boss, but I was often insulted by the workers about my daughter's condition.

Q: Your daughter stayed at home until she was a teenager?

Lin's mother: Until she was about 20.

Q: She never went to school?

Lin's mother: No, she never went to school.

\section{The Girl Kept at Home for Three Years}

Q: Were you the only person who took care of her in your family?

Li Lin: I was very poor in the early days.

Lin's mother: She was locked up at home by me.

Lin: Auntie, you know I was poor, just think about how poor I was.

Lin's mother: What have I told you about interrupting other people's conversations? Stop butting in. 
Lin: Hold on one second, hold on, please. Why did I have to go to the Sunshine Home? When I was at home, somebody beat me (talks to her mother), bullied me, when we went out.

Lin's mother: She is talking about a time that a child threw stones at her when she walked past.

Q: Did you keep her company when she played outside?

Lin's mother: I wasn't there that time.

Q: So she went out without you knowing, right?

Lin's mother: Yes that's right. When she was around 20 and my mother-in-law had passed away, there wasn't anybody to take care of her in the daytime, so I had to leave her locked in the apartment when I went to work. This went on for 3 years before I retired, but after that I continued to work at the subdistrict office for another three more years.

Q: Didn't you worry that she might have an accident?

Lin's mother: Our place was quite safe for her, the plug sockets were high up, even I can only reach them when I stand on a stool. My daughter wasn't able to touch them at all because she's shorter than me. We locked the cooker and gas as well, we only unlocked it when my husband or I arrived home. Basically, we locked the door, the gas, and any dangerous stuff. I came back home and cooked for her during the lunch break.

Q: What did she do at home?

Lin's mother: Watched TV.

Q: Did she only watch TV when she was alone at home?

Lin's mother: Well, except for the TV I didn't give her anything else to play with, just in case she had an accident. Back then, we fixed the electric circuit box on a very high wall to make sure my daughter couldn't reach it; even I couldn't reach it easily. Her dad was good at DIY, so he made a wooden box for the gas cooker. She could only use the water tap, we kept her away from all the dangerous things like the electric circuit box and the fire.

Q: What did you do with her after work?

Lin's mother: I'd work for $3 \mathrm{~h}$ each morning and afternoon as a subdistrict official, I had a lunch break, so I cooked her lunch during my break and took her shopping after work.

I had an accounting certificate, secondary school diploma, high school diploma, and lots of other qualifications, but because of my daughter's condition, I couldn't take other jobs, so I worked at the local subdistrict office. I locked all of my certificates and qualifications in a trunk.

Q: You had to work locally to make sure you had time to look after your daughter?

Lin's mother: That's right. Also, for the same reason, I eventually quit this late job to look after her at home.

Q: How old was she when you stopped working?

Lin's mother: She was in her twenties. 


\section{A Participant of Mother's Community Services}

Lin's mother: I retired in 1996, but carried on working as an official for the subdistrict office for another 3 years, until I became a housewife in 2000. After that, I gave all my time to my daughter. I started doing exercises in the community park every morning.

Q: Did your daughter go to the exercise with you?

Lin's mother: She went everywhere with me. I was a volunteer/teacher in the community. I used to teach lots people gardening, bead making, shoe crocheting. I had a big group of students in the community. Some of them invited me to join their morning exercise, so my daughter would go there with me. She did this group exercise without any real structure or rules for 5 years, until she joined the Sunshine Home. After that, I didn't need to do as many activities as before, but carried on with the morning exercise.

Q: Did she go to the free community classes with you? Did you teach her as well?

Lin's mother: No, she didn't go to the classes.

Q: Did she watch you when you were teaching?

Lin's mother: I taught my classes at home.

Q: At your home?

Lin's mother: Yes, at that time, community activity was a new thing and we didn't have a place to go, so the students would come to my place for their classes. Actually, it was a kind of handicraft club. I got on well with all of my students and they liked to come to my place. Everybody knew I didn't charge anything and I even provided food and materials. I'm a very good cook and I can cook all kinds of dishes, like drunken shrimp, fried dumplings, wonton. I used to cook some delicious things for them.

Q: Auntie, you seem a very capable person to me, very good with your hands.

Lin's mother: Well, I was cooking and teaching them for free, I never asked them for anything. I liked to help others rather than charge them in any way.

Q: So, you used to have activities at your home or in the park and your daughter stayed at home while you went out to the park events, right?

Lin's mother: We didn't go to a park, it was the community garden.

Q: Li Lin didn't go to the community garden with you, she stayed at home?

Lin's mother: Yes, she only went to the morning exercise group with me. But she didn't really know what to do, she would do the set-up exercises at the wrong time and pace. She used to crouch down when everybody else stood up. What a mess! She just didn't understand anything.

\section{She Is Very Interested in Learning Idioms}

Lin's mother: After I left the subdistrict office, my daughter started going everywhere with me and all the people around us got to know her. We live on the East Yuhang 
Road and everybody who lives around the street up to the food market knows my daughter, even though some of them don't know me.

Her face is so easily recognized by people, that's why they know her. Anyway, I liked to take her out when I was free-this was also a time she could learn-I used to teach her stories, traditions, and culture.

My writing has never been great, but I was a good student and I could teach her all kinds of Chinese knowledge, classical Chinese essays, ancient Chinese, and pinyin.

Q: Did you teach her Chinese and math at home?

Lin's mother: Math is not for my daughter, she was unable to learn this, so she just learned Chinese from me. If you ask her about the things that I taught her during that period, she might still remember something. We didn't just recite the idioms, but gave her the context and the relationship with other idioms. If you ask her about the meaning of "Wo Xin Chang Dan", 3 she might not remember all the details, but she could certainly tell you the brief narrative behind it.

Q: Was it difficult to teach her?

Lin's mother: Not at all, she's really interested in the idioms, she doesn't need the same thing explained twice. But if you try to teach her some numbers, her face will turn blank straight away, like a fool, and she stops talking to you.

Q: Did you teach her some simple numbers? Can she count?

Lin's mother: She can't count at all. In this respect, she's just a silly thing. She usually misses numbers here or there and can't count, math is her weakest subject.

Q: But she's good at literature and she really can recall the stories you tell her. When did you start teaching her idioms?

Lin's mother: When she was in her teens, I realized she had a special interest when she was around 15.

Q: You mean she took the initiative in developing an interest in idioms?

Lin's mother: Yes, it's why I started teaching her. I noticed her interest when she started repeating idioms that she'd heard on a TV program. Of course, she couldn't recall them properly, but the interest was certainly there. I started teaching her some simple phrases when I realized her interest. I only explained some of the more complex phrases in more detail when her desire to learn got stronger. Also, I found out she had a special talent for idioms - there was no need to repeat the same phrase twice-but she could never remember numbers.

Q: So, she learned to repeat idioms from TV programs before you taught her, that's right?

Lin's mother: Yes, she was able to repeat them, but she didn't understand how they were used, she could just naturally recall some of the words, and my teaching was based on her desire to learn.

\footnotetext{
${ }^{3}$ Wo Xin Chang Dan is a famous Chinese idiom. It literally means to sleep on brushwood and taste gall; the extended meaning is to endure hardship and to accomplish an ambition. The background story is historical and took place in the Spring and Autumn Period after the state of Wu had conquered the state of Yue. King Goujian of Yue was sent to King Fuchai of Wu's palace as a hostage. Goujian served Fuchai as a most obedient and loyal servant until later Fuchai came to trust him, then Fuchai released him. Later, Goujian spent a long and difficult time preparing for revenge, and finally he defeated $\mathrm{Wu}$.
} 
Q: She didn't understand the meanings of the idioms until you explained them to her?

Lin's mother: Only after I'd taught her.

Q: She started repeating some idioms s before you taught her?

Lin's mother: Yes.

Q: It looks like she knows quite a lot of idioms?

Lin's mother: When she was young, perhaps in her early teens, she learned a new phrase "Feng Zhu Can Nian"" without understanding the context and she said this to my dad who lived in Nanjing: "Grandpa, you're Feng Zhu Can Nian." My dad was very angry. He was a Chinese and English teacher, and this misuse of the phrase on him made it even worse.

Q: Her meaning was her grandpa is old and weak.

Lin's mother: That's right, but as a person of that age, he didn't like to hear something like that. He was angry, but he also taught her the right way of using the idioms: "You mustn't say this phrase to anybody, especially your family." You can understand her grandpa's feeling, right? There's nothing wrong with the idioms and stories on their own, but she shouldn't say them to members of her family.

Q: She used the phrases in the right way after you corrected her?

Lin's mother: Um...

Q: She still makes mistakes?

Lin's mother: Yes, she's probably around 70\% accurate, that's good enough.

Q: She's pretty good, we all misuse phrases from time to time.

Lin's mother: I agree with you. She's getting better now; years ago, it took me several attempts to explain the meaning of "Wo Xin Chang Dan" to her-her verbal ability wasn't as good as it is today. I mean, she could only explain part of the meaning, but now she understands the context and also the meaning of the phrases much better. If I point my finger (points her finger at the table).

Lin: Mei Mu Chuang Qing. ${ }^{5}$

Lin's mother: If I draw a dragon and point at...

Lin: Drawing a dragon, Hua Long Dian Jing. ${ }^{6}$

Q: She knows them very well.

Lin's mother: If I draw a pancake.

Lin: Hua Bing Chong Ji. ${ }^{7}$

Lin's mother: You can see she knows lots of phrases and idioms, at least several hundred.

Q: How did you teach her?

\footnotetext{
${ }^{4}$ Feng Zhu Can Nian literally means a man who is old and ailing like a candle fluttering in the wind; the underlying meaning describes a man who has one foot in the grave.

${ }^{5}$ Mei Mu Chuan Qing means somebody is sending silent messages using his eyes.

${ }^{6} \mathrm{Hua}$ Long Dian Jing literally means to bring the painted dragon to life by coloring in the pupils of its eyes; the underlying meaning is to add some simple words to confirm a vital point.

${ }^{7}$ Hua Bing Chong Ji literally means to draw cakes to allay hunger, the underlying meaning is to comfort oneself with fantasy thoughts without solving the real problems.
} 
Lin's mother: I taught her the phrases by telling her stories. I used to tell her the background and context of the phrase if I knew it. I also taught her some fables in the same way. I was a big reader, and never forgot the things I read, but over $70 \%$ of well-educated people can't recall things after they've finished studying. A good memory also helped me with exam credits, even when I sometimes crammed for exams. As a big reader, one real benefit was I could teach her all kinds of things.

Q: How long did it take her to learn a new idiom?

Lin's mother: She could remember whatever you told her. But trying to teach her numbers was the total opposite, she could never remember anything.

Q: Could she learn and remember the idioms quickly?

Lin's mother: Certainly. She used to laugh away when I told her some funny ancient fable or a two-part allegorical saying. I used to explain the fable "Jie Gan Ru Cheng" through a story she could understand: there was a stupid boy, one day he had to take a long bamboo stick into a room, he tried to hold it horizontally the first time, but couldn't get in; then he stood the bamboo upright, and he couldn't get into the room either. Having failed twice he cut the stick in two. After I told her the story, I also tried to inspire her further with some questions; would he be able to take the bamboo inside if he carried it long ways? I explained the modern fable "Four Men Sleep on One Shoulder Pole" in the same way. My daughter was laughing away after she heard it, because she understood the story straight away.

Q: Now you realise she has a gift for literature?

Lin's mother: Yes, she's really good at Chinese. I can't say she never makes mistakes, but she's fine once you've corrected her.

Q: How did you feel the first time you realized she had this special talent?

Lin's mother: It was strange, because I couldn't work out how someone could have totally opposite abilities with literature and math. Her literary skill isn't perfect, her biggest problem is she can't work out the right context when using some idioms.

$\mathrm{Q}$ : Are you proud of her ability?

Lin's mother: Not really, after all, she doesn't have a sense of numbers and this problem affects her everyday life; she can't use money, for example. I can't leave her the money that I worked so hard to save to her, because if she can't look after it somebody might steal it from her. When my daughter was young, there was no disabled person's allowance, so I would worry about her future and saved every penny I could for her-add 1 yuan to 9 yuan and then I'd have a 10-yuan note; I kept collecting the coins to change 90 yuanto a 100-yuan note. Even though I had to spend most of my salary on my daughter's treatment - and at that time, my salary was only around 40-50 yuan a month-I never stopped saving a quarter or fifth of my income every month.

Q: It must have been very difficult.

Lin's mother: Everything I saved, I did it in this way. I'm not interested in illegal money. I made my fortune in my own way by saving from my daily expenses. If you

\footnotetext{
${ }^{8} \mathrm{Jie}$ Gan Ru Cheng is an old ironic fable about a man trying to bring a very long plank through the city gate, but he fails twice by holding the plank vertically and horizontally. Later, an old wise man tells him to cut the plank in two to make sure he can carry it into the city.
} 
ask my daughter who eats delicious food in our family, she'll tell you it's her and her dad. I rarely eat with them. Even though sometimes I might be a bit greedy with one of the dishes, I only allow myself a couple bites. Today, our family is better off than we ever used to be, but the most delicious food is reserved for them, not me.

Q: You give all your attention to your daughter.

Lin's mother: I used to tell my daughter: "I eat grass squeezed out of milk. I save all the best things for your dad and you."

\section{She Is Independent and Loves Her Family Deeply}

Q: How well can she look after herself?

Lin's mother: She can do some housework.

Q: What kind of housework?

Lin's mother: She started helping with the housework when she was quite young, but sometimes I have to clean up after her, things go wrong occasionally. For example, she used to go downstairs to drop off the rubbish, but she wouldn't come back home straight away and liked to wander around the yard; that's when sometimes she'd be bullied by the other children. Usually, if she spent too long a time downstairs, I had to go and find her to bring her back.

She's good at all kinds of housework, washing up, cleaning vegetables, using the microwave, and the rice maker. I only give her a blunt knife to work with just in case she cuts herself.

Because she can't read, we bought the simplest type of microwave oven and rice maker to make sure she can use them: smart machines are too complex for her. Recently I bought an intelligent microwave oven, a very simple and old model. We only taught her one way to use the microwave, switch on the machine for 2 min at a time. If the milk or food isn't warm enough, then she just needs to repeat this process. With the rice maker you only need to press it once, it's very easy to use.

The really smart household machines aren't suitable for our family. When people see our old-fashioned appliances they think we're too frugal, until they understand our daughter's condition. She can't read at all, it's impossible for her to use a smart machine. We didn't choose the cheapest stuff on purpose, but it's the right type for her.

Q: Can she clean her own teeth and dress herself?

Lin's mother: She's slow, but she's independent. She often wastes time or food. Once, I told her to wash a pair of apples for me, then I saw a huge bowl of water in the kitchen! She used a whole washing-up bowl of water to wash just two apples! What a waste! She might be responsible for a bigger part of our water, gas, and electricity bills. Actually, she'd still be wasting water today if I didn't save and recycle what she'd used in different way. We have a water bucket for the used kitchen water to flush the toilet afterwards, for example.

Q: You're right.

Lin's mother: A big washing-up bowl of water just to wash two apples! 
Q: Does she know how to save the used water in the bucket for recycling?

Lin's mother: Yes, I taught her to do that. These days, her dad is older and he is showing some early signs of dementia, he messes up the toilet from time to time. I have to tell my daughter to clean up the toilet with a special cloth before she uses the bathroom. I also told her to wash this cloth with soap when she takes her shower every evening. She has no problem with this kind of job, she washes the dishcloths quite often as well.

She's a very tidy person, she even checked the bowls that I washed for her when she returned home from her 4-day summer camp.

She's pretty independent these days, she can stay at home by herself, but usually my husband and I will be at home with her, especially after her dad retired. She stayed at home on her own once when I had to go to Changzhou for a factory event and her dad had a business lunch on the same day. She was on her own for about $5 \mathrm{~h}$ and we were worried and almost canceled one of our appointments. Our daughter encouraged us to go: "You don't have to worry about anything, just go, I'll pass the time playing with my Apple and handwriting."

Q: She was okay staying at home herself, then?

Lin's mother: She was that day. I cooked her lunch in advance to make sure she only needed to heat up it in the microwave using the 2-min routine-heat the food for 2 min every time until it's cooked through.

Q: She certainly does what you've taught her.

Lin's mother: Well, her development is from all of our efforts. We've planned for everything for her, knowing her condition and characteristics.

Q: Has she ever done anything that moved you or made you happy?

Lin's mother: I can't say...

Lin: Of course I did...

Lin's mother: Okay, could you tell us something you did that made your mom happy?

Lin: Uh, once, Mom wasn't careful... Somehow, not on purpose, a careless mistake, one time... (She's talking about one time when her mom was sick) What could I do for her? I... Mom had taught me to cook all kinds of dishes, she needed to eat, so I had to cook something for her. I cooked a soup to go with something else for her.

(The mom smiles.)

Lin: I take care of Mom all the time, when Mom had a bad stomach that day, my dad couldn't cook, so I had to cook a meal for her. I cooked an egg dish, something else and a soup; I did all the work myself.

Lin's mother: She can't use the deep fryer or cook fried dish, but she can cook some complicated meat dishes like boiled duck, sliced cold chicken, or other dishes that don't need frying. She also can cook some vegetable dishes like egg custard, cucumber salad, and stewed ribs. She can cook lots of different things, to be honest.

Last time I had a fever for a month and couldn't cook for them, and for a while they had to eat some pretty tasteless boiled food. Later, I had to cook for several days even when I was sick.

Q: Your daughter looked after you when you were ill? 
Lin's mother: Yes.

Q: Did she do all of the work by herself?

Lin's mother: Yes, she worked very hard that month. The taste wasn't always perfect, the rice might be too dry or too wet, the dishes can be a bit salty or too plain sometimes, but I eat anything she cooks for me.

Lin: Once, once... Mom I made a direct ${ }^{9}$ mistake when I was cooking the eggs. They were under cooked.

Lin's mother: You didn't boil it for long enough.

Lin: Mom used the microwave oven to cook them for a little bit longer, and the stuff in the microwave oven was... the egg was flying everywhere.

Q: But she knows how to look after her mother.

Lin's mother: Well, she took good care of me. She's the opposite of her dad in this way. He'd say that he's sick all the time to avoid doing housework, sometimes he even feigns illness. My daughter has never done anything like that, she'll only say she's very sick when she is. Even then, she'll get up and help me with the housework when she feels a bit better. She wouldn't avoid her duty even if she cuts her hand. If it was her dad, he wouldn't be able to leave his bed for days. She wouldn't stop working, it's one of her good characteristics.

Q: She seems like a very sensible child.

Lin's mother: She is, she's definitely a good child when it comes to things like this. When she injured her finger, I wouldn't ask her to help me with anything, but she worried about me and insisted on helping with the housework. Fortunately, her wound healed soon. She never uses illness as an excuse.

\section{She Would Buy Birthday Gifts for Her Parents}

Lin: Once, I bought Mom a skirt.

Q: Really, you bought her a skirt?

Lin's mother: What skirt are you talking about?

Lin: A purple skirt, maybe coffee colored, but you never wore it.

Q: Did she buy you a skirt?

Lin: I bought it once.

Lin's mother: You bought one for me?

Lin: Of course.

Lin's mother: Oh yes, she's right, it was actually a one-piece dress and she spent all of her savings on it. On my birthday when she gave it to me, she said: "Mom, I have a skirt for you."

Q: She bought it for your birthday, she's very generous.

Lin's mother: She was quite sensitive about my birthday.

Q: Did this happen when she was in her twenties?

\footnotetext{
${ }^{9}$ It's Li Lin's word, it's her way of speaking.
} 
Lin's mother: She was over 20 at the time. She knew the dates of our birthdays because we used to tell her before the actual day. These days, when she's at the Sunshine Home, she tells her classmates about my birthday. Then the children would send me "happy birthday" WeChat messages on the day. One time, they even said they wanted to come to visit me. Such a pressure, I had to go down to the Sunshine Home and say to them: "I appreciate your kindness, but please don't spend your money on me. I'm your teacher, and I like to do all kinds of things for you, but I don't want anything in return."

I was just being honest with them. I didn't want to lose my reputation by taking gifts from the children.

Q: Does Li Lin remember your birthday every year?

Lin's mother: She does, because it's very easy to remember, it's the day that follows the Dragon Boat Festival. Her dad's birthday is the day before Spring Festival eve.

Q: Both of your birthdays are very easy to remember.

Lin: Mom's birthday is in the Spring Festival; and dad's birthday is on first day of February. ${ }^{10}$

Lin's mother: You see she knows.

Q: What does she do for your birthday?

Lin's mother: She's stopped buying things for us these days, but once she bought her dad a gift, a pair of trousers if I'm right. But she usually remembers my birthday; she's the same as the other children who are usually closer to their mothers.

Q: Did she buy a gift for you?

Lin's mother: I told her not to buy gifts, she doesn't have that kind of money. I hold on to most of her money, she has some savings from the red envelope gifts that she receives at Spring Festival. I don't want her spending her money on us, but these days she likes to use this "lucky" money to buy DVDs, even a new television, for the family.

Lin: Mom, Mom, Mom, Mom... I'm sorry, last time I did...

Lin's mother: She bought a television for us, she also bought herself a computeractually, it's a tablet. It's a 9-inch iPad; it cost around 3,000 yuan and she paid 1,500 yuan.

Q: She used her own money to buy these things?

Lin's mother: She did, she gave me 1,500 and I paid the rest for her "big Apple".

Q: Do you give her pocket money?

Lin's mother: Sure, but she doesn't usually spend the money, she has a problem using money. I usually make sure she has a 5-yuan note with her just in case the Sunshine Home plans a spontaneous outdoor event. It's money for an emergency bus ticket or some steamed bread if she gets hungry.

Lin: I'm not...I don't buy things myself on purpose.

Lin's mother: Nowadays, she knows how to spend her money on some small things. If she sees a pretty notebook, she might spend 2 yuan to buy it herself. She

\footnotetext{
${ }^{10} \mathrm{Li}$ Lin gave different information about her parents' birthdays; it's probably just a simple error of speech.
} 
always tells us how much she spent afterwards and why, after she spent 2 yuan on the notebook, I topped up her pocket money to 5 yuan again.

Q: So she always has 5 yuan in her pocket, right?

Lin's mother: Yes.

Lin: I just carry the money with me, but I don't spend it very often.

Lin's mother: She doesn't use money very often, but to be honest, she doesn't know how to use it either. Anyway, she only buys small things like a notebook, pen, or other things that costs less than 5 yuan.

Q: What does she do if she sees something she likes that costs more than five?

Lin's mother: Then she'll ask me to buy it for her.

\section{She Never Neglects Study or Play}

Lin's mother: We don't let her play with some ordinary toys or games, but the computer is good for her, we bought it deliberately. She can't read and the computer can't speak to her, so we had to find a way for her to use the computer. We downloaded some emoticons: "hello", "bye-bye" and others she can use, this means she can talk to her cyber-friends using the pictures. For example, she can send an "I'm here" emoticon when she wants to say hello to somebody.

She likes to play with the computer around midnight after my husband and I go to bed. She uses the iPad too much, it's a bad habit, and it affects everything else she does. But she won't change even when we tell her. She will play with her iPad for a while if she wakes up earlier than us, she will only put the machine away when she hears us waking up.

She really lacks self-discipline and I can't handle her. Sometimes, it's hard to tell if she's clever or not, she seems to understand somethings but not much, for example she knows how to turn down the sound right down if she's playing iPad at midnight, so I don't hear her. You can see this contradiction in her studies, she can't understand pinyin even when I try to teach her, but she can read some pinyin and idioms. When she is using the computer or smart phone to chat, she can type some words but not many — she can type my name using the Sougou pinyin software-my name is Wang Chengzhi, the character Zhi means wise, it's simple for the software to create the whole word when you type in the first character.

Q: So the software recognizes how to complete a word?

Lin's mother: I taught her how to make a keyboard shortcut, "WCZ" for my name, so she can find-Wang Chengzhi-in an easier way. So you see, she can't read, but she knows some characters even if it's not many.

$\mathrm{Q}$ : Can she switch on the computer?

Lin's mother: Her computer skills are probably better than yours. She connects to the Internet first, then she'll switch on the computer when the Internet is running.

Q: She can surf the Internet? What does she usually do online?

Lin's mother: Plays games!

$\mathrm{Q}$ : Plays games? 
Lin's mother: Yes, we play a popular online farming game together and she likes to steal vegetables from her friends' farms. I usually tell her off when she makes some wrong decisions. In this game, players have to grow the right kind of crops to certain levels. If she plants the wrong stuff, it might affect her harvest. It's quite funny, I have to be patient and correct her even when she's playing a game. Sometimes, if we're going on a trip, I tell her how to plant the right crop in advance: "If you plan those quick harvest crops that only take several hours to grow, after we've been away for several days they'll go to waste. But if you plant some that take 3 days to grow, they will be ready to harvest when we come back home." I don't play this game anymore, but she still enjoys it.

Q: Apart from playing games, what does she usually do on weekends?

Lin's mother: She practices the side drum on Saturday and Sunday.

Q: She has to practice every weekend?

Lin's mother: She doesn't have a day off, she has to go to the Sunshine Home, and the district Disabled Persons' Federation center. She does all kinds of things except for reading and math. I tell her: "What a shame you couldn't study for a longer time, if you'd behaved better when you were younger you might have got a primary school diploma".

Q: Is she obedient?

Lin's mother: She usually listens to me. It's why I take her out all the time. She understands well enough after I've repeated these things to her again and again. Sometimes, she tells people, if her mom doesn't deal with her bad behavior...she might...

Q: She won't do what you told her not to do, right?

Lin's mother: She understands why I complain or criticize her.

Q: Does she understand that you criticize her for her own good?

Lin's mother: Yes, she knows that. When she was younger, she walked with her feet pointing out, it was awkward, easy for her to fall over when she straightened her back too much. I told her to walk with her feet straight and slowly, keep her chest out and stomach in.

Nowadays, she's big girl, but she doesn't push her belly out too far like some other children in their class. Some children are much bigger than my daughter, very big, perhaps over 15 stone. Now, she walks in a very decent way and she's started criticizing other people who don't walk in the right way: "Well, have a look Mom, that guy doesn't walk well."

Now you know that some people don't walk well, but when I corrected you, you said I was too tough and even said you might not be my daughter (talks to her daughter).

Q: Did she complain that you were too tough to her when she was younger?

Lin's mother: She said I was nasty to her, anyway, I used to correct and criticize how she walked constantly, but at least the way she walks is better these days, right? What a nice thing for her to walk with an open chest and straight back.

Q: I think she's lucky to have you.

Lin's mother: You're absolutely right, she's a very happy and lucky person.

Q: Does she have a phone? 
Lin's mother: Yes, she has one.

Q: Does she use her phone to chat with her classmates on WeChat?

Lin's mother: No, I won't allow her to use WeChat. One of our downstairs neighbors who is a mildly intellectually disabled child, and this child got an 8,000-yuan phone bill on the first month of his contract, and 6,000 yuan for the second month. Altogether, the child wasted 14,000 yuan for 2 months. So I thought she'd better not use it.

Q: She doesn't need a phone.

Lin's mother: I told her that it's better not to use a phone network, the phone is just for me to keep an eye on you.

$\mathrm{Q}$ : Is she able to walk somewhere on her own? I mean from home to...

Lin's mother: No, she doesn't. She doesn't need to go to any places by herself, because I usually go with her when we go out.

Q: You always keep her company all the time?

Lin's mother: Not always, she walks back home from the district DPF center with another boy, a classmate who lives across the road. This boy comes back home with her on school days as well. If this boy can't walk home with her, then my daughter has to wait until I finish my meeting.

Q: Do you go home together?

Lin's mother: Yes, we have to if there's no other choice. Nowadays, she can go to and come back from the Sunshine Home without me, but with one of her classmates, who lives in the same community. She calls me when she's leaving, then I know when she'll be arriving home, if she's late, I might give her a ring. It's about a 15-min walk, but I usually give her an extra 15 min to play on her way back.

The mobile phone amuses her a lot, she likes to call me when she's out. I worry about her when they're out together, because they have to cross several roads. I'm always telling her, your phone is the way to keep in touch and let me know where you are, don't forget to give me a ring when you arrive or leave the home. Anyway, I'll call her if she isn't back within half an hour.

Q: You just said you had to walk her, don't you need to take her to or collect her up from the home anymore?

Lin's mother: No, I haven't needed to pick her up from the home for the last 2 years.

Q: Just these 2 years?

Lin's mother: Almost 3 years now.

Q: She usually gives you a ring or sends a message when she's on the way back?

Lin's mother: She only calls me on the way back or when she arrives at the home in the morning to say: "Mom, I arrived."

Q: Can she walk to the home by herself?

Lin's mother: Well, she's pretty good these days, she can get home from the district DPF center on her own as well.

Q: Can she go to district DPF center by herself?

Lin's mother: She can come back home from there, I've let her try four or five times already.

Q: Do you feel okay about letting her go somewhere on her own? 
Lin: Nowadays, there's a thing Mom can use to find me, the phone. She calls me: "Where are you?" I say: "I'm here, I'll be home very soon, don't worry. I've left the Sunshine Home and will be home soon. I'm on East Yuhang Road... Zhoushan Road.... Baoding Road... I'm arriving."

Lin's mother: I can't really relax when she isn't with me even if she has some friends with her. She doesn't know or care about anything-her personal stuff or the station-when we take the bus journey to the district DPF center. I keep telling her when we go out together that she has to take care of her own stuff, because I have to look after the group, and I don't have time to check her stuff as well.

I criticized her several times when she lost her stuff, now she can look after her own things. I also told her to keep an eye on the route and check the bus stop information, as if she's on her own. Sometimes I tell her that she's in charge of the group trip and needs to remind us when the right bus arrives at the stop if anybody asks.

I had to do this because she never took any notice of the bus journey over the past 10 years. I kept telling her to remember the names of the stops: "You can't read but you can hear the automatic announcements, at the same time, you'd better try to remember the familiar buildings near the stops." I used to "threaten" her: "If we miss the stop, I'll slap you afterwards."

Q: Did your threat work?

Lin's mother (laughs): More or less, but I needed her to remind me when I forgot the stop sometimes.

Q: You travel together, but she has to be the one in charge of the journey?

Lin's mother: That's right, I let her lead the journey. Sometimes, she'd forget to get off at the right stop if she was chatting with somebody. So, because of this, I would say: "If you forget to get off and need me to remind you, I'll slap you later."

Lin: Nothing hard, just a couple of gentle taps.

Lin's mother: Sure.

Q: Did she make the mistake that you just mentioned?

Lin's mother: Of course, it's easy for her to miss the stop when she's talking. When I was testing her, I realized she wouldn't make a mistake if I wasn't talking to her, it's all about concentration. Can you understand?

Q: She needs to concentrate on the journey and mustn't be distracted.

Lin's mother: You're absolutely right.

Q: Is she able to open the front door?

Lin's mother: At first her hands would tremble when she was trying to open the old lock, but nowadays she doesn't have any problems with the new lock. The old door lock was an easy one, but the new one, has a safety lock that has taken her a long time to get used to.

Q: How long did it take you to teach her that?

Lin's mother: More than a week, perhaps around 2 weeks.

Q: Well, that's pretty quick.

Lin's mother: Sometimes her key gets stuck in the lock; when that happens, I won't say anything but let her dad criticize her. It's the difference between my husband and me, I'm more patient with her than her dad. 
She's okay with the phone, because she doesn't need to use the keypad, we've set up a contact list for her already. When she needs to make a call, she only has to type "mom," "dad," or other names. A phone call costs 10 pence, but a message only needs 5, so we taught her to write some very simple messages like "I've arrived" or "I'm leaving."

Q: Did her dad teach her to use the phone?

Lin's mother: Um.

Lin: Dad isn't as attentive as mom, he tells me off sometimes.

$\mathrm{Q}$ : What was the relation like between Li Lin and her dad when she was younger? What did her dad do for her development?

Lin's mother: When our daughter was younger, under my led... her dad taught her how to hold a drumstick in the right way, because she was too nervous she might drop them and used to hold the sticks too tight.

Q: Your husband and you used to teach her to play the drum together, didn't you?

Lin's mother: Um, he told her the right way to hold the sticks, hold them with relaxed fingers, and tap the drum gently for a better sound.

Q: Did her dad teach her some idioms when you were teaching her?

Lin's mother: Occasionally, he corrected a mistake, but it's mostly about his mood.

Q: Did her dad take her to the park or morning exercise?

Lin's mother: Sometimes. Once when she was very young, a teenager, I made my husband take Li Lin with him when he had to go to Nanjing for a business trip, because her maternal grandpa lived there. He didn't take her out often because he didn't want his colleagues to know about her, but that time was a business trip and it was just the one time. I told him to leave the girl with her maternal grandpa when he went for a walk. Before that, my daughter went to Nanjing with me several times and knew the area a little bit, so she could recognize her maternal grandpa's place. Finally, my husband agreed to take her with him, and she led her dad to her maternal grandpa's home.

Q: Did she know where to go?

Lin's mother: She knew, because compared to Shanghai's lanes, Nanjing's lanes are much easier to remember. She surprised her dad, he was happy and told me: "She took me to her maternal grandpa's place, even though I knew the way less than her."

\section{She Can Read and Write Simple Characters}

\section{Q: Can she write her own name?}

Lin's mother: Yes, she can write her own name, but her handwriting is terrible. Her family name is "Lin," 11 the character is two "woods" combined; she writes the character in two separate parts, it looks like two separate "woods" characters to other people (laughs). I told her to write the characters closer together, but she doesn't listen to me.

\footnotetext{
${ }^{11}$ Lin, the Chinese character is “林”, which includes two “木” (wood).
} 
She also has other problems with the structure of characters, sometimes the character might be too far apart or too close together. When she receives her meal or travel allowances from the district DPF office occasionally she has to sign the documents. Her handwriting is ugly but I won't sign for her, I just let her sign them however she wants.

Q: Can she write any other characters, in addition to her name?

Lin's mother: She can write most of her classmate's names at the Sunshine Home. I didn't know she could write these words until she pointed out some characters to me when we were out together. Now I know that she knows some simple characters on advertising boards, but she has to ask for my help with complex characters.

She doesn't know pinyin, but she knows some radicals and some characters that include the radicals.

Q: When did she start learning characters?

Lin's mother: Well, in the last few years. But she still can't tell the time, she doesn't understand the 24-hour clock. She'll be confused if you tell her 13:00 or 14:00, now, at last, she knows 14:00 is 2 p.m.

$\mathrm{Q}$ : When exactly did she learn that?

Lin's mother: In the last 2 years.

Q: Who taught her to tell the time, the Sunshine Home or you?

Lin's mother: She learned it at the Sunshine Home and from her classmates at the district DPF center. Sometimes, the children need to write articles, but my daughter can't write long paragraphs. One of the boys usually helps her with her writing and homework. He's a boy from our drum team; he likes to please me by teaching my daughter because I' $m$ their teacher.

Q: What do you mean by "child"?

Lin's mother: It's what we call the students. Most of the mildly intellectually disabled children are educated. If she needs to write something, my daughter would ask somebody to help her and then joked with me: "I have a secretary!"

Q: She lets somebody write things for her?

Lin's mother: Yes, I teach those students and in return, they help my daughter.

\section{Travel Has Been an Eye-Opener for Her}

Q: Does she like to stay at home or go out?

Lin's mother: She likes to go out.

Q: Do you let her stay at home sometimes?

Lin's mother: Yes, she can, but she likes go out as well. Well, she likes to go on trips!

Q: Does she tell you when she wants to go on a trip?

Lin's mother: Yes, it's usually her idea. She hasn't been to Beijing and she told me: "I want to go to Beijing, because I haven't been to our nation's capital yet." It's a trip I owe her, but haven't had a chance to organize it yet.

Q: Do you take her on trips very often? 
Lin's mother: Yes, we go on holiday quite a lot! I don't try to save money anymore because I don't want my money to go to somebody else. What's the point of saving money just by cutting down on our daily expenses?

Q: Where have you been with her?

Lin's mother: We've been to a lot of places: Thailand, South Korea, Hainan Island, Zhangjiajie. Traveling is good for her intellectual development.

\section{She Gets a Lot Out of the Sunshine Home}

Q: You said when she was little, she was a naughty girl. When did she become more sensible?

Lin's mother: When she started at the Sunshine Home in her thirties. She was quite a naïve young woman before that.

Q: The Sunshine Home had a real impact on her.

Lin's mother: Yes, she's made great progress, and her development was perhaps the best of all the children at the Sunshine Home. She's learned idioms and fables, but she doesn't understand numbers. With this poor sense of numbers, if you ask her where she lives, she couldn't tell you the exact address, because she forgets part of the information every time. For example, if she told you the apartment number, she might forget which floor, or the other way around.

Q: She can't remember the complete address?

Lin's mother: That's right, she can't remember the name of the street or the phone number. She used to get very nervous when she answered the phone.

Q: She didn't like answering the phone?

Lin's mother: She didn't know what to say, anyway, she didn't know how to use the phone.

Q: How many years has she been at the Sunshine Home?

Lin's mother: Ten years.

Lin: Which month did I start there? Was it December or June?

Lin's mother: She joined the district DPF center on 9 February 2006; and she joined the Sunshine Home in July 2005.

Q: You know these dates very well.

Lin's mother: I'm not good at dates, but I remember these things so I can teach her. My daughter made me remember them (smiles).

Q: She asks you about these dates?

Lin's mother: I tell her without her asking.

Lin: Do you know how I found this place? Once day a member of staff at the Sunshine Home visited us, I didn't want to go at first, then...

Q: What does she study at the Sunshine Home?

Lin's mother: To be honest, the Sunshine Home has a lot of problems; for example, they overprotect the children from accidents. They just keep the children in the classroom from early morning to 3 p.m., when they finish.

Q: Don't they have any activities? 
Lin's mother: Now and again they have some activities. Normally, they don't do any active things other than the People's Radio Calisthenics, because the home is located in a residential building. They might get complaints from the elderly people if the students are too noisy.

Nobody wants to take responsibility for them, the less accidents the better, and it's the same at the subdistrict office. There are some sensitive parents who might give the home or subdistrict office a hard time if anything happens to their children. For example, we took a taxi to a gymnastics competition today and for safety reasons the district DPF officials divided the students into small groups for each taxi; they would rather spend more money than let them take a bus. Sometimes, when the students need to go somewhere together and they don't have enough officials and full-time workers to look after them, some of the parents, like me, have to travel with them.

This morning, I had to look after three of the children in a taxi. The subdistrict office doesn't want any accidents to happen to these children, and the Sunshine Home teachers are even more afraid of taking on this kind of responsibility. So these children don't do anything more challenging than sit in a classroom for the whole day.

Once, one of the teachers said something bad to my daughter and after she told me about this, I went to the home to talk to the teacher. The teacher denied the whole thing. I was angry with the teacher at the time. I lost face, but I can't blame Li Lin. Sometimes, an articulate child can get into trouble.

Well, after this incident, I didn't talk to this teacher again. Some of her classmates, they are also my students in the drum band, aren't very nice; they overheard the argument between the teacher and Li Lin, but they wouldn't be a witness. Now, I feel they've let me down - they wouldn't help in a crisis-even when I give them so much love. I'm just wasting my time, right?

\section{She Cares About Her Classmates and Likes Making Friends}

Q: Does Li Lin like making friends?

Lin's mother: Of course.

Lin: I like making friends very much.

Q: Did she have any friends before she went to the Sunshine Home?

Lin: No. (Here, Li Lin answers the question with English).

Q: No?

Lin: No, not really.

Q: Li Lin was mostly alone before she joined the Sunshine Home and then she got to know a lot of classmates and became part of the class. Did you feel uncomfortable when you first went there?

Lin's mother: She didn't have any problems.

Q: So she was able to fit in straight away?

Lin's mother: Yes. Before she went there, a subdistrict official visited us. After I told him that my daughter had never been to a school, he said he was worried that my 
daughter wouldn't survive at the Sunshine Home. Surprisingly, she adapted quickly and could understand most of what the teacher was saying. One of the teachers even said my daughter has a strong sense of justice.

Q: She seems get on with her desk mate very well, they were chatting to each other during break time when I was there.

Lin's mother: Yes, Li Lin is close to her; when this girl was young, she was behind with her studies because she was in hospital so often with tracheitis. Her intellectual development was slow, she also has eye and foot problems; she's a disabled person, but not intellectually disabled.

Q: Does your daughter keep in touch with her classmates during the holidays?

Lin's mother: They do talk to each other, and she's able to understand what they're saying.

Q: Do they go out together after school?

Lin's mother: No, I don't let her go out with them.

Q: Why?

Lin's mother: Well, some of those students are much more developed than my daughter, so I don't like her going out with them.

Q: What's her relationship like with her classmates?

Lin's mother: She cares about her classmates; she likes to bring snacks for them at the Sunshine Home or the district DPF center. These days, I have plenty of money to buy her snacks, but she likes to save some for her friends, whether it's a delicious cake or expensive chocolate. She likes sharing with other people. Sometimes, those children ask her for snacks as well.

In winter, she likes to take some herb teas, like chrysanthemum, Goji berry, or orange peel tea. She never says no to her classmates if anybody asks her: "Do you have herb tea today? May I have some?" Sometimes, when we have some snacks that are too hard for my teeth, or I don't like them, my daughter will take them to the home. She usually asks me before she takes snacks to the Sunshine Home: "Mom, one of my friends wants some of your snacks." She's a caring child.

She has pity for some of the children who have lost their parents. There's one child, his unreasonable dad died suddenly one Chinese Spring Festival. He'd divorced with his wife and had sole custody of the child. Following that, this child had to have surgery to remove a kidney and then received dialysis treatment later. Then his mother had to take him back to look after him, but she couldn't do this properly because she wasn't a well-educated person.

These days, I have a higher moral threshold then before. I don't only think about my own daughter, but also the other children. So, when I tell my daughter to take some extra snacks and food to share with her friends, it's like I treat these children as if they were my own.

Q: Did she understand the teacher's orders like "sit still," when she was first joined the class?

Lin's mother: Of course.

Q: Was she well disciplined? Didn't you say she was a hyperactive girl when she was little?

Lin's mother: Yes, she couldn't sit still for a minute. 
Q: Could she sit still when she started at the Sunshine Home?

Lin's mother: No, she couldn't, but she developed a new hobby-handwritingthis kept her occupied and still, it stopped her from messing around.

Q: She's certainly able to enjoy the Sunshine Home experience, because she has a mother like you, doesn't she?

Lin's mother: No, not at all. Nowadays, the teachers who don't have a disabled family can't understand what our life is like-sometimes their management approach can be a little bit selfish - they don't have the same caring character as we do. We have more love than these teachers, we have plenty of empathy for these children who have lost their parents.

Q: You feel upset for those children?

Lin's mother: Yes, so now we're looking to get more attention from society.

Lin: There's another poor girl who comes from a two-child family. She was fine before their mom died, but now the younger child bullies this girl.

Lin's mother: The non-disabled young sibling bullies the girl, that's why we didn't have another child.

Q: You mean that you worry your daughter would have been bullied by a younger sibling?

Lin's mother: What?

Q: You just said that you decided not to have a second child.

Lin's mother: We were worried that we might give too much attention to the second child - if we had had another child, they would have had to be a normal child. During this child's college entrance examination period, I would definitely have focused on his/her study and nutrition and wouldn't have been able to look after Li Lin as well as I do now. Li Lin's a minx and she wouldn't allow this to happen.

Q: She wouldn't allow you...

Lin's mother: No, she wouldn't let us have a second child. She used to say: "Where would you leave me if you get a healthy child? You won't look after me anymore." She won't allow my husband and Ito play mahjong or dance, because she worries "you might lose me in a mahjong game, no one else would care for me; if you met somebody else dancing, our family wouldn't exist anymore."

Once, I said to her: "Huang Ling is very poor-should we invite her to stay with us for the Spring Festival, just for a couple days?" She said no. I asked why and she replied: "I can't share my mom's love with anybody." She's quite selfish in that way. Another time, she was crying about the poor orphans who lost their parents in the Wenchuan Earthquake. I said: "You don't need to cry, we can adopt one of them and it'll be a good thing for the government and the child." She didn't want to have another sibling, absolutely not. She would rather donate money to these children than adopt them. She's been insecure in this way since she was very young.

She's also very careful with our money. She doesn't earn very much, but she doesn't like us to use our savings either. She's a demanding child and always begs me to buy her some snacks when we go out together, but sometimes when I don't have enough change or I think the stuff is too expensive, I have a special way of stopping her. I pretend to walk to the bank. Then she gets nervous and stops me by 
dragging me back. She doesn't want me to withdraw money from my bank account, and tells me: "Mom, we can ask Dad for some money later."

She controls my money and at the same time, my behavior. Nowadays, she doesn't worry when we go to the bank together like she did when she was younger, because she's sure I won't waste money. She also understands her mom is a good woman and has stopped worrying about me, but she was very anxious when I used to go out dancing, even though I never flirted with other men when I went dancing. She was really worried about losing me.

Q: She was insecure when she was younger, but now, she understands things better?

Lin's mother: She knows me better now, but she still gets anxious with other people; she knows she's a lucky child, compared to other children.

\section{She's Made Great Progress in the Drum Team}

Lin's mother: These days, she learns more from the district DPF drum team than from the Sunshine Home. The district DPF plays a very important role in her development. She used to leave everything for me to look after when we went to band practice, but now she can take care of her own personal stuff. My job in the band is to look after the group's belongings, so I have to tell her to keep one eye on her stuff, and she's pretty good at that.

Q: What does she do there?

Lin's mother: When we arrive at my office, she'll wash up cups and pack up some food that's been opened; if somebody leaves a flask in the classroom then she'll take them to the office. And she looks after her own bag; I don't need to worry about her anymore.

In the band, she isn't one of the smartest children because of her disability. I feel guilty about my daughter's poor performance, so I always go to the events with the volunteers and teachers. The band leader, who comes from the district DPF office, told me: "You've taught so many students, why can't your daughter learn like them?" I said: "Because my daughter isn't that clever, otherwise she would have learned it already." "I don't believe you, I'm asking you to teach her again until she knows the new movement." So, we'll go to the center tomorrow, borrow two drums, then together practice the new drum routine "Chinese Kongfu."

Q: Will you do that this year?

Lin's mother: Yes, during the 1-month holiday.

Lin: I'll also learn some new idioms in the Spring Festival, and recite songs as well. Can I recite something for you?

Lin's mother: Do that later.

Lin: I want to recite it for her. (She's talking about reciting one of the famous military songs for the interviewer.)

Lin's mother: Do you really want to recite this? Do it later.

Lin (she looks a bit nervous): I just want to recite a little bit of it. 
Lin's mother: Okay, fine, you just do it.

Lin: The troop arrived in Zhaxi in February, the reassembled troop looks well organized. We developed the guerrillas in Southern Sichuan, the company was more than three thousand people. Then, the troop arrived in West-Northern Sichuan in July. What are we working hard for? Fighting the Japanese so we can rescue China. ${ }^{12}$

Lin's mother: Teacher Zhou from the district DPF office, who is in charge of our group, told her to remember the lines of this song; it took her... She's getting there this week.

Q: It only took her 1 week to remember the whole thing?

Lin's mother: No, longer than a month.

Q: It took her over a month to remember it?

Lin's mother: She could only recite it properly for the first time this week. She read it to Teacher Zhou already, and she said: "Li Lin did a good job." I explained to her that my daughter could only do this because she had time to prepare.

Q: She needed several days longer than the other children.

Lin: My classmates taught me as well, it wasn't only my mom who taught me; two boys helped me as well.

Q: So, her classmates and you taught her together?

Lin's mother: Yes, those boys live in the same neighborhood with us, both of them are drum band students as well. I get on with them pretty well, I used to take some snacks for them and they like to talk to me about personal things now and again. If we need to go somewhere, the boys usually go with me for safety reasons. They're obedient children and they usually listen to me; they help my daughter to please me.

Q: So, Li Lin can recite the lines but she can't actually write them?

Lin's mother: She can copy the lines if you write down the characters first, but that doesn't mean she understands the words.

\section{She Practices Hard and Looks Forward to Performing}

Lin's mother: I'm so pleased we have a drum team. You might have seen one of our shows on TV? There's an old guy, a high-rank official, who worked at the Security Bureau. His son has epilepsy, and he understands disabled people's families very well. When he retired, he put together a drum team for the disabled children to give them a chance to get out of the house.

Some people told him that these intellectually disabled children wouldn't be able to play the drum, but he didn't give up. Now, all of our children can play. We come to the district DPF center every weekend to practice the side drum and the flat drum, dancing, singing, and learning English. Our children go to the Sunshine Home from Monday to Friday and go to the center every Saturday and Sunday.

\footnotetext{
${ }^{12}$ The Red Army Overcame The Long March is a part of the Long March Song Cycle. They are famous Red Army songs, stories of the troops who were involved in the Long March, between October 1934 and October 1936.
} 
My daughter was determined to join the drum band when she saw the children playing. She just thought that it was an interesting thing to do, but she didn't understand how hard the training would be.

Q: Did they have to sign up for the band?

Lin's mother: Yes. I didn't let her go, I told her she couldn't join the band at first, because I thought she's not very good at things like this, and wouldn't be able to learn how to play. Later, after she joined the band, I'd criticize and smack her when she didn't keep up with the practice.

Lin: Um... She hit me so many times.

Lin's mother: You joined the band even when I told you not to (talks to Li Lin).

Q: How did you join the band?

Lin's mother: Not me, she did it.

Q: She did it?

Lin's mother: When she found out that she couldn't play the thing, she said to me: "Who would have known that playing the drum would be so difficult? I wouldn't have joined if I'd known how difficult it was going to be." (She's laughing).

Q: How did she find out about the district DPF band?

Lin's mother: She heard the news from her classmates at the home, because the district DPF officials walk around the subdistricts to recruit new people.

Q: So, she got the information from other children?

Lin's mother: She was encouraged by them, because the band didn't have enough players and they were looking for more children. The recruitment teachers wandered around the subdistricts and the Sunshine Homes and approached the students. To be honest, the man, the founder, was very strict, That's his disciplinary style because that's the way he was with his charges when he was an official.

Q: How's she doing with her side drum?

Lin's mother: We haven't started our home tutorials yet, because we haven't been able to borrow drums from the center; when we get them, I'll have to train her much harder, because that's what the band leader wants. I have to teach her every piece of the choreographed movement this week. Playing the drum is a kind of interactive dance, you have to move the body and the drum from front to back together.

Q: Can you give me more details?

Lin's mother: The dance involves a lot of turning around, but my daughter doesn't understand what a $90^{\circ}$ or $180^{\circ}$ turn is, that's what I need to teach her.

Q: Do you have to teach her one thing at a time?

Lin's mother: Yes. For a full rotation, you should start with a left turn, then do four left turns together and then you'll be back facing the original way. That's this week's homework (see Fig. 1).

Q: That's the only thing you're practicing this week?

Lin's mother: Yes, she only needs to work out those turns this week and we'll practice more movements for the middle part of the dance later. She's pretty good with the beginning and ending already.

The rotation sequence is the basic movement for the whole dance, we have to start with it, and this means that my daughter has to start practicing 1 week earlier than the other students. I've even drawn a diagram of the dance action for her. 
Fig. 1 Li Lin practicing side drum

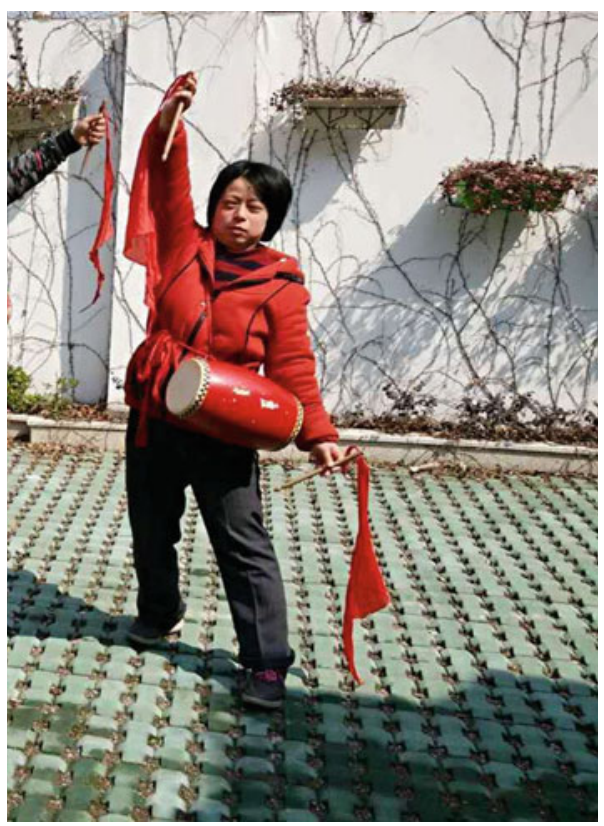

Lin: Mom says... Mom said: "Walk to one side, turn to that side again, now turn again. The left hand turns back while the right hand turns to the front."

Q: Auntie described the movements in great detail.

Lin's mother: I told her, a $90^{\circ}$ turn is turn once to the side, a $180^{\circ}$ turn means you turn twice, the body faces the back. I drew the picture to show her what turning right and turning left means, I've tried all kinds of ways to help with this.

Q: Can she understand you?

Lin's mother: She's a little bit more enthusiastic today.

Q: She's enthusiastic, how long have you been teaching her?

Lin's mother: It's taken me a whole week. At first, she didn't understand the idea of turning round at all. I'm under pressure from the band leader, that's why I had to start teaching her a week early.

Lin: Do you know how much pressure it's been? He said, "I'll fire you if you can't learn the routine." That's how serious it is!

Lin's mother: The team leader said he might fire her and she doesn't need come to practice anymore.

Q: How long do you teach her every day?

Lin's mother: It doesn't take that long, because I can't teach her too much at once. I thought about teaching her earlier but I got sick last month.

Q: Do you practice every day?

Lin's mother: Yes, every day, for about $2 \mathrm{~h}$ more or less. Before the performance, we used to have a week of intensive practice like this, training every evening for a week. 


\section{Q: Every evening?}

Lin's mother: Sure. Playing the drum is noisy and disturbing, so I let her practice from 4 to 5 p.m.; this is the best time for everybody, she won't disturb our neighbors. At this time, the second shift workers haven't come home, and the night shift workers are having their dinner, and the early morning shift workers are cooking. Anyway, 4-5 p.m. is our training time.

There are some other students who can't play the drum, they are just there to make up the numbers. I told them the best time to practice at home as well. I said that you have to practice harder because I'll check up on you next time, you'd better practice in the early evening. If anybody complains about the noise, you can just say: "Can you think of a better time? It's the best time I know; I haven't disturbed your dinner or sleep." "You have to remember that this is our only practice time," I told them.

Q: Has she ever been to a performance?

Lin's mother: Yes, she's been to some shows. After she'd just joined, she couldn't catch the instructions from the teacher-standing in line, understanding discipline, "at attention," "hull," turning back-until I taught her little by little. I taught her to turn to the same side with other players because she has to keep in line if she wants to join in the performance, it's what she wanted to do.

Q: So, for example, if your daughter can't understand to turn left when the teacher tells her, you'll give her a lesson at home, right?

Lin's mother: Yes, but even now, she's not great at turning round. She likes to watch the other students while they're dancing.

Q: Looks at other students?

Lin's mother: She's usually slightly slower than the others, so she'll follow her classmates after they move.

Q: How does she know to keep one eye on the other dancers?

Lin's mother: I told her to do it.

Q: So, Auntie taught her.

Lin's mother: Haha, otherwise she wouldn't be able to dance at all! At the time she didn't know anything. I told her secretly that she shouldn't stand in the front row but hide behind the others. Now, she knows the dance better than before, so I said: "You should stand just behind the best dancer and follow her/his actions, but don't stand at the back, because you won't learn anything there."

Q: She'd better imitate the good learner.

Lin's mother: I also told her that she had to move to the back row when the teacher comes to check on them (laughs). Nowadays, I don't teach her as hard as before. She'll be fine if she can learn 70\%. For the other 30\%, I'll teach her when she's ready and wants to learn. I can't teach her when she hasn't worked out what the new dance or movements are.

In our band, the clever children, the mildly disabled ones, received a free drum from the district DPF center, but my daughter wasn't one of them, so I had to pay 200 yuan to buy her one. It's a luxury toy.

Once the band was invited to perform "Without the Communist Party, There Would Be No New China" at a Happy Sporting Meet. Li Lin couldn't play at all. She would just make up the numbers when they were practicing, but this was a formal 
event. Before the show, I had to train her very hard, the side drum wasn't available to take back home, so I'd use duvets to make a surface the same height as the drum and let her use a pair of wooden sticks for drumsticks. Later, I took her to the square for further training; we trained very hard, until a dog walker stopped us and said: “Auntie, she's as good as you now, you don't need to practice so hard anymore." I would only let her stop when I thought she was good enough for the performance.

Q: So, she trained very hard and put a lot of effort into it.

Lin's mother: It was very hard work for her.

But the teachers at the Sunshine Home are just happy to let things stay as they are. They won't teach students the Ninth Edition of the People's Radio Calisthenics, the latest version. When the parents suggested they learn the new one, the teachers just said they can't even do the eighth version properly yet. So, my daughter had to go to the district DPF center to learn the new things or learn it with me. I taught her slowly and made sure she understood the rhythm of the movements; before she learned this, she used to move around too quickly, without the rhythm.

Q: Does she like to attend group events?

Lin's mother: Of course, she likes the events very much. If she didn't, I wouldn't need to do all this work. Can you imagine my situation? My daughter's disability is moderate to severe, the band teachers despise her and they won't allow her to stay in the group to make up the numbers when they have a show. They made me pretty angry and I couldn't work out why. I didn't ask them for anything much, just an opportunity for my daughter to be a part of the performance. Besides, I'm one of nine parent teachers; except for my daughter, all the other eight children have a place in the show... I totally lost face.

I was angry with the band about this, but my daughter is determined to go to the practice and I have to force myself to go with her. I really don't want to go. Why do I have to suffer embarrassment? I have plenty of money, I'm a volunteer, I don't ask for anything in return. I really don't need to suffer this.

But what I can do, my daughter loves it. I have to suffer this for her, for her happiness. It's why I kept telling her, all the social work I'm doing now is just to give you a better life.

I know my daughter is moderately to severely disabled and she can't take part in some of the more formal competitions and events, but she's perfectly able to join some shows with the drum team or radio calisthenics. She can just make up the numbers.

I don't ask too much of her but stay in the position-she mustn't turn to the left when the others turn right, or crouch down when the others stand up-she has to keep the same routine and pace. I told her that she has to stop at the same time as the other people when they shout a slogan. At times like this, she has to keep her head down and don't do something different from the others.

Lin: Once, I wasn't careful...

Lin's mother: I criticized her very seriously.

Lin: I shouted "yeah" too early, just after you said it when we were taking a picture together. 
Lin's mother: Later, I gave her a very serious lesson. I criticized her very seriously. I said: "What did I you tell you before? Why did you make the mistake and shout at the wrong time again?" The band leader, that old chap asked me: "Why are you criticizing her?" I said because I told my daughter to be careful with her actions, she shouldn't shout louder or out of rhythm with the group, but she...

Lin: Once Mom said I didn't play the drum well, and I practiced until... that day when we were... I got very upset after she criticized me so many times. I felt I'd been discriminated against by people. Even my mom said something nasty to me... I really wanted to quit at that moment. I felt very bad.

Q: When did this happen? Did she tell you she was upset?

Lin's mother: Something like that, occasionally, but not very often. She wasn't good at expressing herself and used to speak incomplete sentences.

Q: How did you feel when you heard that?

Lin's mother: It was a bit hard to laugh (smiles), because I was exasperated that she couldn't get it right. I was angry and there was nobody else to get angry at. I don't have anything in common with the outsiders who have their own families and children. I don't have anything to say to them.

Lin: And, sometimes, I used to say to mom: "Sorry. If I was an ordinary person, Mom would probably have grandchildren by now."

Lin's mother: At that time, I was working at the subdistrict office. One day I was chatting with my colleagues and suddenly, she said to me: "Mom, I'm sorry you can't be a grandma." Her words surprised my colleagues, they couldn't understand why she would say something like that (laughs).

Q: How did you feel when she said that?

Lin's mother: (She's smiling) I thought she's sensible, more sensible than before. I can't tell you how many times I cried for her when she was little. It was a very hard time, but when she was in her twenties, she started telling me: "Mom, you worked so hard to look after me." She'd heard somebody else say something like that to me.

\section{Working Hard Now for the Life Hereafter}

Lin's mother: When she couldn't play the "AAB" tune on the drum-it's not something for everybody - I used to teach her by playing with a pan lid or the washing-up bowl. The leader of the band, the old chap, praised me for teaching my daughter so well. He even found out I'd been an excellent worker before I retired.

To be honest, I always think that having this child has been a punishment for my bad behavior, or I didn't worship God enough in the last life...(she laughs) that's why I have her. Now, I have to do more good things for a better afterlife. I must do good things only. I'm always saying I have to dedicate myself to do good things for a better afterlife, especially after I must have failed in my last life. So, I'm always the good one wherever I work, I never offend anyone. People like me, because I never criticize anyone to their face if they make a mistake, but point out the problem in a gentle way. After the band leader discovered my reputation, he invited me to join the 
teaching team, but at that time, my thoughts weren't as pure as they are now. I just thought this will be good for my daughter.

Q: Now your daughter is part of the band.

Lin's mother: It was mostly for safety reasons, when I joined the band as a teacher, she could come with me to the center. I didn't have to worry about her getting back safely with somebody else. At first, it was just for my daughter, but now I've been doing this work for over 10 years.

I teach them to make beads, not just the elderly and the children, but also their parents. As a parent of the Sunshine Home, I don't just teach the children, but also provide beads and other materials for them. During the summer holiday, they used to invite me to give a bead-making class to the children when they organized events. I would bring my own beads and other materials to teach them.

Q: Do you usually teach children?

Lin's mother: Usually they're my main group. In addition, I have three parents' meetings each week, Tuesday, Saturday, and Sunday, and do exercises every Wednesday. I also give computer lessons from time to time. I'm very busy. I have to make free time to look after my family's financial investments (laughs).

Q: You have a full schedule.

Lin's mother: I like to do knitting and make beads when I have time, I made this pretty tablecloth!

Q: Do you teach your daughter?

Lin's mother: No, she can't work with the beads at all, putting one bead on a string, it's the only thing she can do. All the children learned the skill except my daughter. There's a student, called Xiao Yiming, who's a warehouse keeper. The other teachers and I taught him computer skills. After he learned some basic skills, he left the class and joined a computer training program and earned a business administration degree from a college. Now, he's graduated and works at an old people's home. That's pretty good, right? He's a caring child and comes to see us at the festivals. None of us expect a gift, but he always brings one.

Q: He wants to express his appreciation.

Lin's mother: These children are sensible. You might not think so, but they know who really cares about them. He said to us, "We don't like to be criticized by the teachers except Li Lin's mother, because she really cares about us." As you can see, these children, they might be a bit wild or have a bad temper, but they know us, the teachers care about them; they are clever enough to understand this, even though it took them a while to work it out.

I've been moved by these children, everything I've done for them has been worthwhile. They know what I say or do is just for them. Sometimes I'm quite strict. I criticize them when they mess up. Some of them said: "I'm not angry with Li Lin's mother when she criticizes me, because she's doing this for my own good." I'm tough with them, sometimes I criticize them when I'm exasperated by their failure to do well, because there aren't many people who care about them, and I have to take responsibility. 


\section{Now the Mother Is in Her Seventies and Isn't in Good Health}

Lin's mother: I had a light stroke in November. If I turn too fast, I get dizzy. I've had some problems every year... One year I had headaches, and a numb tongue, this year, the problem is dizziness. I even feel dizzy when I'm in a car, and I'm unsure on my legs. One time, when we were training at the entrance of the People's Park, I had to stop teaching her the spinning dance after I became really dizzy. I couldn't stand up. I gave up teaching her because of the dizziness, also because I didn't have any pressure to teach her at that time. This time, now the weather is getting warmer, I'll start again.

Last week the band leader told me: "I really don't understand why your daughter is the only one who can't learn the dance. I have to tell you that if she can't catch up with the other students, I'm afraid I won't be able to keep her in the band." So I said: "It's not her fault, I'm responsible for it, because of my health problems, I haven't been able to teach her properly."

I can't turn around, especially spin around, with my daughter and she needs me to show her the same actions several times. I have a number of health issues now-can you see how my face is swollen? (points to her face) I've made an appointment at the tumor hospital to have it looked at.

Q: Auntie, please take good care of yourself.

Lin's mother: Before I received the test results, I was under a lot of pressure because I've been told that this type of tumor might be nasty. I'm frightened to death. I'm not worried about myself but for my daughter. The only thing I can do is go to see the doctors. This heavy pressure is making my face worse.

$\mathrm{Q}:$ Are you all right now?

Lin's mother: I'm better now, but I still feel it; the swollen lymph nodes can't be cured even if I take medicine every day.

Q: So you usually worry a lot?

Lin's mother: When I was standing in the queue for the test, several people in front of me were given bad news about their tests. This upset me and I felt under huge pressure. That day, I left in the dark, took the earliest bus at 5 a.m., changed from No. 17 to No. 49. I had to stop myself thinking about it too much when I arrived at the hospital. Finally, the result revealed I was fine. I told the doctor I don't have other problems except for cystic oviducts. It was at one side at first, but now both sides are affected. The doctor said the cystic oviducts isn't the cause of the swollen lymph nodes (points to her face).

The rest of the tests went well. After the swelling had gone, I went to a gynecology hospital and took another cystic oviducts test and the doctor said the swelling had disappeared. I couldn't believe the result. I guess the underlying problem is still there, but the tumor has shrunk. I can relax a bit and have a good Spring Festival with the family now. Otherwise, I won't stop worrying about it. I'm 70 this year and I'm worrying that I might not last much longer.

At my age, few people can dance, sing, or play with their children like me, especially when I have such a heavy family burden; it's why I was so upset when my 
daughter couldn't do her best for her dance. This year, according to the Chinese lunar calendar age, I'm 70 already, and I'll actually be 70 next June. Can you imagine how tired I am having to do all this for my daughter?

\section{She's Still Concerned About the Future}

Lin's mother: For parents like me, our only concern is the future of our children after we die. Maybe you've heard some stories about the old people's home, if we leave the children with them... On our street, there's a child who is in the same situation as my daughter. His parents have some money and decided to move into the old people's home. The only condition was that they could take their child with them. The manager said that they would be welcome, but not their child. So, what happens to our children when we die? Even if an old people's home agrees to take our children after we die, we still have to worry that they say one thing to our face, but do exactly the opposite behind our back. They might treat our children well before we die, but after we pass away, they might only look after the children when the inspector visits. I even don't dare to think about this thing, so, the best thing for us is that our children die before we do.

Q: Has she ever thought about getting married?

Lin's mother: I don't want her to get married, because there are too many twofaced men who would spoil your daughter when you're living together but throw the girl out and keep all of her money after you die. There are too many stories like this. Too many disabled people's marriages end badly. Li Lin's future mother-in-law might look down on her as a disabled daughter-in-law; the situation can be worse than you think.

Right now, whoever is responsible for her when we die is a real family issue. I'll try my best to arrange something for her after I die. The government would be better than our relatives. My older maternal sister who lives in Nanjing used to say to me in front of my daughter: "You're welcome to visit me, but you mustn't bring your daughter with you." She's my relative but even she thinks about my daughter like this. Every time we go to Nanjing to visit my parents' tomb, we have never stayed at her place even though she has a three-bedroom apartment. We used to stay at a hotel and eat out, and I didn't want to eat at her home.

Q: One day she'll be alone...

Lin's mother: Well, it's a family problem, and I've decided to let the government look after her.

Q: The government?

Lin's mother: I want her to join a "house-for-pension" scheme, because I have a property that I can pass down to her later. If there's a day when she loses all her money, she would still have a place to live; anyway, she has an allowance. Her dad disagrees with this plan. He insists: "My nephew, niece, and their children will look after her." How could I trust them? They've never cared about her. I don't think it's possible for them to take care of her. 
Q: Her dad wants her to live with his relatives?

Lin's mother: Yes, right now we're in the middle of a "cold war" over this. I'll leave the property and our daughter to the government if he dies first, but if I die before him, the thing might go the other way. We wish the government would set up a special care home for these children with high-quality workers. Otherwise, we would never be at ease leaving the children with the current group of workers. Take the nursing homes as an example. You might have heard some stories about the number of new arrivals who've died there in the last few months to a year. On the one hand, it might be related to the health of these people; but on the other, some cases are down to a lack of care or bad service.

Of course, the government takes this issue very seriously, but implementing policy isn't as good as it should be. We think that because these workers aren't family, they give a poor service. Mildly disabled children have a regular income and affiliated workplaces before they retire. After that, they'll receive a pension. But moderately to severely disabled children only have a minimum allowance and no pension provision. It's why I feel helpless about my child's future; the policy treats the two groups of children unequally.

Q: Do you mean a mildly disabled child has a better income?

Lin's mother: A mildly disabled child, can be affiliated to a company. They'll receive a pension monthly when they reach retirement age.

The biggest problem is that some bad people might steal their money, but they'll get income again the following month. They're very vulnerable when they have to deal with money themselves and without their parents. They won't have anybody to look after them. Most of the children don't have a sense of the value of money, even for the children who are more intelligent than my daughter. They can't work out what change they should get from a 100-yuan note. They can be cheated too easily.

Q: Can't she buy a soft drink herself?

Lin's mother: Not my daughter, but some of the cleverer children can.

Q: Can't she?

Lin's mother: It's not possible, she doesn't even understand numbers up to 10 .

Q: What's her degree of intelligence?

Lin's mother: Degree three, she's closer to severe rather than a moderate condition. Being articulate, is her only advantage.

Q: Do they have allowances?

Lin's mother: There are two different kinds; a person who has a mild condition will receive a minimum wage, and there is a minimum allowance for moderately and severely disabled children.

This year has been a good year for them, surprisingly, their allowance increased a little through two new policies. Her minimum allowance was around 900 yuan, but now it's been increased to 1150 yuan. She has also started receiving two additional benefits; a 350-yuan special subsistence, and 150-yuan rehabilitation subsistence. In total, she gets 500 yuan more than before; it's much better than we expected.

Q: The government has quite a big budget for this group of people.

Lin's mother: Well, it's a lot of money, but her allowance is still less than a mildly disabled child's. Our biggest worry isn't about what's happening now, while she's 
living with us, whether she has her own salary or not, we're able to look after her. It's about her future, when we die, what kind of social care will there be, who'll take care of her. The central government has no policy about this yet, but we desperately need one as soon as possible. There are two key issues for us; one is that somebody or an institute will look after her after we die, or I would hope for her to die before us to make sure we can give her a secure and happy life.

Lin: I don't want to leave any trouble for mom. If I die... if I die before you, please throw my ashes in the sea.

Lin's mother: Of course, I'll go to rest in the sea as well, because there will be nobody to visit our tombs or pray for us even if we had a tomb.

Q: That's all of the questions I want to ask. Thank you for telling Li Lin's story to us, we appreciate it very much.

\section{Interview with Li Lin's Teacher}

Interviewees: Teacher Wang and Li Lin's mother

Interviewer and writer: Yunxiang Zhang

Interview date: June 26, 2017

Interview place: Sunshine Home

Q: Are you Teacher Wang?

Teacher Wang: Yes, that's right.

Q: How long have you been Li Lin's teacher?

Teacher Wang: Six years, more or less, since the two Sunshine Homes merged.

Q: How able is she? And her attendance?

Teacher Wang: Her attendance is pretty good; she hardly misses a school day.

Q: As her abacus teacher, what do you think about her ability?

Teacher Wang: It's not so good. She's quite practical and good at thinking, but she's terribly bad at math. I can't figure out the reason. In class, when you explain something to her, she would say: "No problem, I understand," but if the question is more complex, she'll soon get lost (smiles).

Q: How about her attitude to learning?

Teacher Wang: She isn't bad in this respect; she wants to learn new things, she likes to finish her homework.

Q: What happens if she can't answer a question in class?

Teacher Wang: She'll ask me to explain the question to her.

Q: Is she frustrated when this happens?

Teacher Wang: This thing happens quite often. Let me try to describe her problem... She likes to ask a question if she can't answer it in the first place, but then you'll find out she's asking a different question. Sometimes, when we are talking about one thing, she'll change the question to another one.

Q: Is she quite interactive with the teachers in class?

Teacher Wang: Yes, she's pretty interactive. 
Q: Does she like activities outside the class?

Teacher Wang: She's very active in this respect.

Q: Does she get along with her classmates?

Teacher Wang: She's not bad, she likes to help her classmates, especially one student who has bad eyesight. She has the social skills to avoid conflicts with other students, generally speaking, they're quite friendly with one another.

Li Lin's mother: I used to show her how to get along with her classmates, what she should do or not do; never get involved in anybody else's business.

Q: Has there ever been any conflict between her and other students?

Lin's mother: No, there hasn't.

Teacher Wang: She doesn't have any serious problems with her classmates, but sometimes her stubbornness can appear in some small issues. How should I say this, she's an "I'm-always-right" kind of person (laughs). If she thinks she's right about something, she'll insist in this right up to the last minute - she has to argue, she even makes excuses.

Q: You mean if she thinks she's right—even if she's not right—she'll argue her case.

Teacher Wang: You're absolutely right. In her mind, she's always right, always. If she's not right, she has to find a way to make it happen (he's laughing away).

Years ago, the two subdistrict Sunshine Homes, Xingang and Tilian Bridge merged. I was working at Tianlan Bridge Home and the students there were quite laidback people and got along well with each other. But Li Lin's old cohort, compared to our old students, were more active and used to argue with each other.

One day, after the two homes had merged, Li Lin came to me to say that two monitors-Liqin Liang and Jiawei Sun, who came from different classes-had a confrontation when they were washing their lunch bowls in the public bathroom. So I talked to these two students and asked them what had happened. I said to Liqin Liang: "Did you argue with Jiawei Sun and tell him to wash the bowls?" Liang said: "No, we didn't do any such thing, I just told him to wash the bowls properly that's all. There was no argument." I said: "But Li Lin told me you had a fight." Then I asked Li Lin to come along and tell us what she saw. She insisted: "You guys argued, didn't you? Both of you raised your voices and fought about who should wash the bowls." (He's laughing again). That time, after we established the facts, Li Lin agreed and apologized straight away, but when she went back home, apparently, she told you a different story (talks to Li Lin's mother), her own story, because for her, what she saw was definitely the only truth, and she couldn't have been wrong.

Q: She probably just felt she should apologize at that moment, but didn't change her mind.

Teacher Wang: You're definitely right.

Lin's mother: Li Lin said her classmates were two-faced.

Teacher Wang: She insists on her own versions as the truth (he's laughing).

Lin's mother: When this kind of thing happens, she'll argue with them first, and if she can't win "the battle" with words, she'll even hit them. I will criticize her seriously if I hear she's done something like this. But she'll never admit to a mistake 
in the first place—usually, it takes a while for her to apologize if it's her fault—it's how she is.

Q: Now you've been Li Lin's teacher for several years, have you noticed the progress she has made?

Teacher Wang: She's made great progress. Now she looks very independent to me. She can do all kinds of things-she can certainly wash her own bowl very well.

Lin's mother: The cleanliness of the bowls she washes is guaranteed.

Teacher Wang: She's become a highly capable girl and she's able to do everything herself, but some years ago, when I first met her, she couldn't do most of the things that she's good at today. Her mother had to force her to learn.

Lin's mother: She still can't remember phone numbers; she doesn't have a sense of numbers.

Teacher Wang: She's much better than in the past. For example, she couldn't write when she came here, but now, if you give her a copybook she can draw characters even though she's not as quick as other students. Her essay writing skills are getting there little by little. She wasn't able to write this kind of thing — an essay that students write after activities and events - her schoolmates used to give her their work for her to copy. After she copied the essays, stroke by stroke, character by character, her writing has become much better.

Q: She can copy characters and essays, but she can't explain her own feelings and thoughts, can she?

Teacher Wang: That's right, but she's very good at explaining her feelings through language, she certainly can do that very well.

Lin's mother: She never needs to prepare if she's speaking.

Teacher Wang: She's a very good speaker. Once, when we went to summer camp together, she told a story about her great parents, it made all the teachers weep. That's the truth! One of our teachers was swept up with emotion about the difficult life $\mathrm{Li}$ Lin and her parents lived. She told us how her mother washed her cloth nappy in the cold winter and other details; the story really touched the teachers' hearts and made us cry. She's a very good storyteller (smiles).

Lin's mother: That was the story how my daughter was born in a cold winter and I had to warm up her cloth nappy before I put it on her in case she felt cold.

Teacher Wang: Li Lin said her mother had to put nappies on her own belly to warm them up before she put them on Li Lin. In those days, people didn't have air conditioners or other heating appliances, so her mother had to warm her nappies in this way. Li Lin's story, well, really... it was touching (he's laughing).

Lin's mother (laughing): Her stories can make people cry, she's a very good talker.

Q: How could she remember these stories from her childhood?

Lin's mother: Well, she has her own ideas.

Q: Can she remember things that happened to her when she was a child so clearly?

Lin's mother: She can remember them well enough after I've told her the stories.

Q: How long does she speak, usually, for example, on a topic about her gratitude to her parents?

Teacher Wang: She can talk on this topic much better than others. On that occasion, the story competition was about $20 \mathrm{~min}$, but she took up to $45 \mathrm{~min}$. She kept talking 
about those tiny, subtle details that happened in her life. She could remember all of them!

Q: Did she prepare before the event or just make them up?

Teacher Wang: She hadn't prepared. Even the teachers only received a lastminute note. That evening, we were called to a meeting and one of the host teachers announced that we would have an impromptu competition: every subdistrict home had to name two students for a storytelling competition to share their stories about their gratitude for their parents and teachers. Xiao $\mathrm{K}$ and Li Lin represented our home, but Xiao K's story was much shorter than Li Lin's.

Q: Why did you choose Li Lin?

Teacher Wang: I didn't, Teacher Xu Sheng chose her, but both of us agreed that Li Lin was a good talker. In our class, she sometimes speaks more than her teachers (he's laughing). Anyway, she's a very good talker, but she can't write anything down. Also, she can talk about so many details, that's a part of her ability to express herself (laughs again).

Lin's mother: She can keep talking about one thing forever (she's laughing, too).

Q: She has this very strong speaking ability in class.

Teacher Wang (he keeps smiling): She's pretty good, very good.

Lin's mother: And the officials of the subdistrict office didn't think she would be able to join the Sunshine Home.

Teacher Wang: It's about a perspective of policy; the home is for children with medium or mild disabilities; we hardly ever offer a place to a child with a severe condition. The purpose of the home is to provide a place for them to develop their skills through everyday classes. We can't take responsibility in the same way as a nursery, looking after babies and feeding them when they're hungry.

Q: How about her abacus performance in your class?

Teacher Wang: She can work with some simple numbers if she practices with the other students. In group practice she can follow her classmates if she doesn't understand how to do it herself. She'll be fine if I tell her to put "two" on her abacus, but then she wouldn't be able to calculate two plus two. Our addition and subtraction practice is only simple, but she can't do it without watching her classmates. A poor understanding of math is her weakness (smiles).

Q: I noticed that she was struggling with the abacus when I attended your class last time.

Teacher Wang: You're right.

Q (smiles): I also realized that last time, in the classroom, you didn't ask her to answer your questions.

Teacher Wang: On the one hand, the learning progress of the students is uneven; on the other, we have to meet the set teaching programs-when the district DPF office tells us to move on to Book Two, we can't stop for slow learners. We have to finish our set teaching material. If they want to learn something new, they can improve themselves in their break or at lunch time; if they can't reach the class's target, there's nothing we can do for them except to tell them to try to remember those formulas.

Q: Do you offer students who are falling behind extra help during lunch time? 
Teacher Wang: We offer this for those students with a stronger learning ability, like Xiao L or Xiao C; if they have any questions, we like to help them.

Lin's mother: These days, she has a stronger interest in Chinese language and literature; she can write characters and pinyin with a copybook independently. This is something new she has learned at the home; now she can even copy the English alphabet from a copybook.

Q: She can certainly copy those characters, but does she understand them?

Teacher Wang: I'm afraid she only knows some simple characters, but not the complex ones. She just draws them using the copybook.

Q: What classes do you have except for the abacus?

Teacher Wang: We have English, math, domestic science, Special Olympics training, rehabilitation training, and personal hygiene classes, too many. We usually have two classes, one in the morning and one in the afternoon each day.

Q: How about Li Lin's concentration in class? Does she pay the same amount of attention in both the morning and afternoon classes?

Teacher Wang: She's not bad, usually her performance is better at the beginning than at the end of the class, if her classmates are quiet. If anybody makes a noise, she has to get involved with their business straight away (starts laughing).

Lin's mother: Li Lin concentrates on writing better than anything else; otherwise, she likes to "manage" the other students.

Q: What about her everyday performance, apart from the fact that she's too easily distracted by other students?

Teacher Wang: Generally speaking, she's a good student, she takes her study quite seriously.

Q: Which class do you think is most helpful for her?

Teacher Wang: Perhaps it's the rehabilitation training, this deals with body exercises, like radio calisthenics and dancing-she loves this kind of activity. She also enjoys the singing class very much.

Q: She was very active during the singing event when I was here.

Teacher Wang: She likes to sing; last week the class went to karaoke together where she was singing with several other students. She was humming the tune even though she couldn't read the subtitles on the screen (laughs).

Q: It's pretty difficult to learn a new song if you can't read.

Teacher Wang: Sure, it's not easy to remember the lyrics without being able to read.

Q: Do you teach the music class as well?

Teacher Wang: Yes, I do, we have to teach so many different things. The teaching program requires us to teach them a new song every month, but one song can take much longer than expected. For example, we taught them a new song after the Spring Festival, but some students still can't sing it yet.

Lin's mother: Some students who have that talent learned the song immediately. One of them learned Yue Opera with his grandma; with this kind of musical training, he can sing along with you if you start humming a song.

Q: What is Li Lin's learning ability like in class?

Teacher Wang: She's just about okay. 
Q: Is she better than some other students?

Teacher Wang: Yes, some students are worse than her.

Lin's mother: There are quite a lot of students who don't understand a thing. They're not like my daughter, she seems to understand your meaning but only from time to time (she's laughing away).

Teacher Wang: She can certainly understand if you point out her mistakes, but with the worst students, they won't understand you and they can get angry with you at the same time.

Q: It's a difficult balance for you and the other teachers.

Teacher Wang: It's not too bad, I'm fine with whatever they like (he smiles). Basically, they're obedient.

Q: I think all the teachers of the Sunshine Home are very kind and positive.

Teacher Wang: We're okay, we try our best. We haven't charged the students for lunch since 2005. Some homes have to charge 150 yuan because there is a shortfall in students' monthly lunch subsistence-but our subdistrict office and the district DPF office covered the budget gap for us. It's why the students who register with the Tilan Bridge subdistrict office get a free lunch, but we have to charge a little bit of money from some students if they come to our home but have registered elsewhere, because we won't receive their food subsidy. Somebody suggested we charge some money for every student, but how can we do this to them? We can't do it.

Q: Could you tell us one thing about Li Lin that has impressed you the most?

Teacher Wang: She has a very good heart, but sometimes she likes to make things up. Once, when we were on summer camp, she wanted to sleep over in Teacher Sun's room.

Q: Do you mean the summer camp where Li Lin told the story?

Teacher Wang: No, this was another camp. The camp site was in the Songjiang District. Each teacher had to share a room with three students, so Li Lin, Xiao S, and Xiao Z were with me. But suddenly, when I was in the shower room, Li Lin told Xiao S that she was moving to Teacher Sun's room. Xiao S asked her why, and she said because her friend Xiao T was in that room and insisted she had to go, otherwise she would get angry with $\mathrm{Li} \mathrm{Lin}$. Then, from outside the bathroom, Li Lin asked me if she could go to Teacher Sun's room.

I said: "You can only go if Teacher Sun says yes. I'm not sure if they have enough space for you, so you'd better ask her first." She said: "There is space for me, and Xiao T will get angry if I don't go." So, I agreed to let her go. Later, after we came back from the summer camp, she told her mother a completely different story; she told her mother that she had changed rooms because Xiao S didn't like her snoring and that I had kicked her out. It was totally untrue. She just made up the story for her mother (he's laughing away).

Q: So, she told two different stories to you and her mother at that time?

Teacher Wang: The story behind it was, Li Lin is very close to Xiao Y and Xiao G, but she'd had an argument with Xiao S in the past-Xiao S can be an aggressive person, she'll beat you up if you're not very nice to her-so these two shouldn't have been together. I didn't know this story when I arranged the rooms until Teacher Sun told me. She said to me I'd better not put these two children together. I replied: 
“They'll be fine this time, because I'll be keeping a very close eye on them." But the story about her snoring and changing rooms still happened... She definitely told me, her mother, and other teachers several different stories. She can really make up a story.

Q: But why?

Teacher Wang: I really don't know, she just enjoys telling stories, she's clever enough to know which story you don't like (keeps laughing).

Q: Does Li Lin go to this kind of summer camp often?

Teacher Wang: She goes to summer camp every year because she's independent enough to look after herself, showering and feeding herself.

Q: Do they need to take a shower and have meals on their own?

Teacher Wang: Of course, they have to be independent to this level; the camp is also a chance to prove their abilities. It's quite an independent experience for them. They have to spend 4 days and 3 nights with their teachers and friends but not their parents. When the teacher tells them to carry out a duty, they have to be able to do it independently.

Q: The camp has many activities, how often is this event, once or twice a year?

Teacher Wang: There are two camps for eight subdistrict offices every year. They only can offer places to three of the subdistricts each time. If one subdistrict office cancels, the other seven offices take turns in the camps. There's a special site for the event.

Q: Could you make a final comment about Li Lin?

Teacher Wang (he laughs again): It's impossible to do that in a single sentence.

Q: You can say more if you like.

Teacher Wang: Let me think about how to describe her. For me, she's a person who likes help others.

Q: She's eager to help others.

Teacher Wang: Also, she always the first person to clear up the place. She's that kind of person, she volunteers for all kinds of responsibilities (he's keeps smiling).

Q: She's very enthusiastic.

Teacher Wang: Yes, she's a very enthusiastic person. There's anything else... I can't think of anything (he's laughing away).

\section{Observation of Li Lin at the Sunshine Home}

Observation date: 9:00-15:00, December 14, 2016

Observation place: Sunshine Home

Observer and writer: Yunxiang Zhang 


\begin{tabular}{|c|c|c|}
\hline Time & Content & Observed activities \\
\hline 9:00 & $\begin{array}{l}\text { The early arrivals watch TV while they } \\
\text { wait for the other students to come }\end{array}$ & \\
\hline $9: 10$ & $\begin{array}{l}\text { Li Lin opens the gate of the home and } \\
\text { walks in. She calls her mother after she } \\
\text { sits down and takes out her paper and pen. } \\
\text { Then she comes and says hi and shakes } \\
\text { hands when she sees the observers }\end{array}$ & $\begin{array}{l}\text { All the students, with the teacher's help, } \\
\text { have to open the gate themselves. Li Lin } \\
\text { looks a bit sleepy when she walks into the } \\
\text { classroom, she keeps turning back with a } \\
\text { smile to look at the observers }\end{array}$ \\
\hline $9: 19$ & $\begin{array}{l}\text { Li Lin stands in the second row during } \\
\text { radio calisthenics }\end{array}$ & $\begin{array}{l}\text { Li Lin sorts out her clothes and the } \\
\text { clothes and hat of the student in front of } \\
\text { her. Her performance is out of tune, but } \\
\text { her movements are good. She } \\
\text { concentrates on the exercise and seems to } \\
\text { enjoy it very much }\end{array}$ \\
\hline $9: 32$ & $\begin{array}{l}\text { After the exercise, she comes back to her } \\
\text { seat where she's left a notebook she took } \\
\text { out earlier from her bag and chats with } \\
\text { her desk mate. Then, she starts writing }\end{array}$ & $\mathrm{Li}$ Lin is very quiet when she writes \\
\hline $9: 36$ & $\begin{array}{l}\text { She leaves the seat and walks to the } \\
\text { bathroom }\end{array}$ & \\
\hline 9:40 & $\begin{array}{l}\text { When she returns, she puts her notebook } \\
\text { in the drawer and chats with her } \\
\text { classmates for a while. She starts playing } \\
\text { with her abacus }\end{array}$ & $\begin{array}{l}\text { Li Lin tells her desk mate that she can't } \\
\text { write on the abacus with a pencil, that } \\
\text { won't work }\end{array}$ \\
\hline 10:00 & $\begin{array}{l}\text { Class begins, the teacher asks the students } \\
\text { to practice the abacus }\end{array}$ & $\begin{array}{l}\text { During the practice, Li Lin's mother is } \\
\text { teaching her. When somebody answers } \\
\text { the teacher's question, Li Lin applauds } \\
\text { with the other students and says "Great, } \\
\text { great, you're great," to him }\end{array}$ \\
\hline 10:06 & $\begin{array}{l}\text { Li Lin stands up and tries to answer the } \\
\text { teacher's question "Can you add eight on } \\
\text { the abacus," but she has to sit down after } \\
\text { the teacher chooses another student to } \\
\text { answer the question }\end{array}$ & $\begin{array}{l}\text { Li Lin listens very carefully when the } \\
\text { other students are answering the question }\end{array}$ \\
\hline 10:25 & $\begin{array}{l}\text { Following the teacher's instructions for } \\
\text { addition and subtraction with her hands }\end{array}$ & She makes quite a lot of mistakes \\
\hline $10: 30$ & $\begin{array}{l}\text { During break time, Li Lin takes out a pen } \\
\text { and writes something down, but she } \\
\text { erases it afterwards. Later, she drinks } \\
\text { some water from her flask and puts it } \\
\text { back in her bag }\end{array}$ & She drinks slowly \\
\hline $10: 40$ & $\begin{array}{l}\text { After a rest, Li Lin sits down and sings } \\
\text { "Sit Up Straight" with her classmates. } \\
\text { Then they open the book and start to } \\
\text { practice again }\end{array}$ & $\begin{array}{l}\text { She can't follow the teacher's guide even } \\
\text { though her mother is next to her helping }\end{array}$ \\
\hline 11:05 & $\begin{array}{l}\text { The teacher asks them to clean up the } \\
\text { room while Li Lin is out }\end{array}$ & \\
\hline
\end{tabular}


(continued)

\begin{tabular}{|c|c|c|}
\hline Time & Content & Observed activities \\
\hline $11: 15$ & $\begin{array}{l}\text { When she comes back the classroom, } \mathrm{Li} \\
\text { Lin chats with her classmates }\end{array}$ & \\
\hline $11: 25$ & $\begin{array}{l}\text { Lunch time, she stands in the queue with } \\
\text { her classmate }\end{array}$ & $\begin{array}{l}\text { Li Lin takes her bowl to get food from the } \\
\text { teacher and thanks him afterwards. The } \\
\text { lunch includes rice, egg, and steak }\end{array}$ \\
\hline $12: 00$ & $\begin{array}{l}\mathrm{Li} \text { Lin stops one of her classmates } \\
\text { looking at an observer's phone, she also } \\
\text { reports this to the teacher }\end{array}$ & \\
\hline $12: 25$ & Handwriting time & \\
\hline 13:25 & Bathroom time & \\
\hline $13: 30$ & Prepares for entertainment time & $\begin{array}{l}\text { Li Lin cleans her desk and puts the chair } \\
\text { onto the desk before she stands up. She } \\
\text { claps her hands and taps her feet, she } \\
\text { looks very excited }\end{array}$ \\
\hline $13: 45$ & $\begin{array}{l}\text { They play a clapping game together. They } \\
\text { clap hands together and count from } 1 \text { to } \\
37 \text { while they're marching on the spot }\end{array}$ & Li Lin looks very happy \\
\hline 13:50 & $\begin{array}{l}\text { She comes to show the observer how to } \\
\text { dance while she's moving to the rhythm }\end{array}$ & \\
\hline 13:55 & $\begin{array}{l}\text { A classmate sings on the teacher's stage, } \\
\text { she listens very carefully while she taps } \\
\text { the rhythm with her fingers and moves } \\
\text { her body. Later, she opens her hands wide } \\
\text { and claps hard }\end{array}$ & Her body movement is very exaggerated \\
\hline 14:00 & $\begin{array}{l}\mathrm{Li} \text { Lin taps the desk and talks to her } \\
\text { friend while another student starts singing }\end{array}$ & $\begin{array}{l}\text { She enjoys the classmate's song very } \\
\text { much; she applauds enthusiastically and } \\
\text { is very happy }\end{array}$ \\
\hline 14:05 & $\begin{array}{l}\text { She turns back and smiles at the observer, } \\
\text { then carries on her dance }\end{array}$ & Li Lin looks very happy \\
\hline 14:10 & $\begin{array}{l}\text { Everyone sings "A Grateful Heart" } \\
\text { together. Li Lin joins in and uses sign } \\
\text { language }\end{array}$ & $\begin{array}{l}\mathrm{Li} \mathrm{Lin} \text { is excited; she claps her hands and } \\
\text { moves around }\end{array}$ \\
\hline 14:15 & $\begin{array}{l}\text { Li Lin is chatting with her friends while a } \\
\text { student sings "My Happiness Is I Miss } \\
\text { You" }\end{array}$ & \\
\hline 14:20 & $\begin{array}{l}\mathrm{Li} \text { Lin and the two other students come to } \\
\text { the front of the classroom and sing "My } \\
\text { Happiness Is I Miss You" }\end{array}$ & $\begin{array}{l}\text { Li Lin is very active; she starts to sing } \\
\text { even before the teacher asks her }\end{array}$ \\
\hline $14: 25$ & $\begin{array}{l}\text { She moves her arms when one of her } \\
\text { classmates sings "Run" }\end{array}$ & \\
\hline $15: 00$ & The class ends & \\
\hline
\end{tabular}


Open Access This chapter is licensed under the terms of the Creative Commons AttributionNonCommercial-NoDerivatives 4.0 International License (http://creativecommons.org/licenses/bync-nd/4.0/), which permits any noncommercial use, sharing, distribution and reproduction in any medium or format, as long as you give appropriate credit to the original author(s) and the source, provide a link to the Creative Commons license and indicate if you modified the licensed material. You do not have permission under this license to share adapted material derived from this chapter or parts of it.

The images or other third party material in this chapter are included in the chapter's Creative Commons license, unless indicated otherwise in a credit line to the material. If material is not included in the chapter's Creative Commons license and your intended use is not permitted by statutory regulation or exceeds the permitted use, you will need to obtain permission directly from the copyright holder.

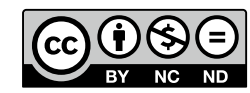

